\title{
THE FIRST AMENDMENT AND THE SECREGY STATE: SNEPP V. UNITED STATES
}

\author{
Jonathan C. Medow $\uparrow$
}

For the American intelligence community, the 1970s was a decade to forget. One scandal after another basked in the spotlight of national attention, and by the end of the decade, the accumulated destruction was considerable. Ruined careers, curtailed powers, and diminished public confidence lay amid the wreckage.

The 1980s promise great change for the intelligence community. The political mood of the country, as the most recent elections evidence, has shifted dramatically. The people no longer want to hear about corruption and its reform; rather, it is time, they say, to let the professionals do their job. The Supreme Court apparently agrees. In Snepp v. United States, ${ }^{1}$ the Court, without benefit of briefing or oral argument, ${ }^{2}$ handed the Central Intelligence Agency (CIA) a watershed victory in the Agency's battle to contain the flow of information to the public. In doing so, the Court granted the Agency even more than it had stated it needed. ${ }^{3}$ So incredible was the Court's result that a shocked Jus-

† A.B. 1978, Stanford University; J.D. 1981, Harvard University. Member, Illinois Bar.

The initial draft of this article was written under the supervision of Professor Laurence $H$. Tribe during the author's final year at Harvard Law School. The author wishes to acknowledge the invaluable assistance Professor Tribe rendered. All conclusions and, of course, all errors are attributable to the author and the author alone.

1444 U.S. 507 ( 1980 ) (per curiam).

2 For a criticism of this aspect of Snepp, see Cox, The Supreme Court, 1979 Term-Foreword: Freedom of Expression in the Burger Court, 94 HARv. L. Rev. 1, 8-10 (1980).

3 The government won its case on the merits in the district court. The court of appeals affirmed on the merits, but reversed an award of all profits from Snepp's book and remanded for a determination of punitive damages. Snepp petitioned for certiorari on the merits of his first amendment claim; only at that point did the government cross-petition, asking that its petition be granted only if Snepp's was. Before the Supreme Court, the government expressly stated that the court of appeals' result was "sufficient" for its purposes. Snepp, 444 U.S. at 525 (Stevens, J., dissenting) (citing cross-petition for certiorari). The Court granted both petitions, but disposed of Snepp's contentions in one footnote, spending the rest of the decision on the question of remedy, finally reinstating the district court's award of profits from Snepp's book. Justice Stevens chided the Court for its approach: "Given the Government's position, it would be highly inappropriate, and perhaps even beyond this Court's jurisdiction, to grant the Government's petition while denying Snepp's. Yet that is in essence what has been done." Id. 524 . 
tice Department at one point publicly stated that it would not exploit the decision for all that it was worth. ${ }^{4}$

The case centered around Frank W. Snepp III, a former CIA agent who became disillusioned with the CIA over the agency's role in the United States' withdrawal from Vietnam. In order to express this disillusionment and the reasons therefor, Snepp wrote a book. The book discussed the Agency and was published without CIA approval. This combination of facts, the CIA reasoned, constituted a violation of the "secrecy agreement" Snepp had signed as a condition of his employment. The Agency filed suit against Snepp, urging this theory among others as a basis for recovery. From a legal perspective, the case was interesting primarily because it posed the question whether first amendment considerations rendered the secrecy agreement unenforceable-or so one would have thought. The Supreme Court needed only one footnote ${ }^{5}$ to dispense with Snepp's first amendment challenge.

This Article analyzes the correctness of that abrupt conclusion. Towards this end, part I sets out the Snepp case in detail. Part II then describes the exact restraints imposed by the secrecy agreements Snepp signed. Part III examines whether such restraints would be constitutional if applied against private citizens, a term here defined to include all legal persons who have neither worked for the CIA in the past nor signed a secrecy agreement. Part IV then considers whether those who have signed these agreements have thereby waived any first amendment rights. Finally, part $\mathrm{V}$ discusses the relevance of prior CIA employment.

Two groundrules must be stated. First, it is assumed that no problems of statutory authorization exist, in that Congress has fully endorsed and sanctioned the secrecy agreement practice. This assumption, as numerous others have remarked, ${ }^{6}$ has no basis in reality; ${ }^{7}$ it is made solely for analytical purposes. The purpose of this Article is to analyze the merits of these restraints under the conditions most favorable to the government's position. Threshold issues are not the focus. Second, terms such as "reveal," "disseminate," and "speak" are not meant to encompass the act of

4 See Boston Globe, Dec. 13, 1980, at 6, col. 2. The Reagan administration has indicated it will observe no such restraint. Chicago Tribune, Dec. 14, 1981, at 19 , col. 1 .

5 Snepp, 444 U.S. at 509 n.3.

6 See, e.g., Comment, Government Secrecy Agreements and the First Amendment, 28 AM. U.L. REv. 395, 424-25 (1979); Comment, National Security and the First Amendment: The CIA in the Marketplace of Ideas, 14 HARv. C.R.-C.L. L. REv. 655, 693-98 (1979).

7 But see Snepp, 444 U.S. at 509 n.3. 
making a private, unauthorized disclosure to a foreign agent. Pure espionage is not the topic. This Article's concern is rather with the constitutionality of these restraints when applied against activities enjoying more presumptive first amendment protection. ${ }^{8}$

\section{The Snepp Litigation}

\section{A. The Facts}

Frank Snepp joined the Central Intelligence Agency on September 16, 1968. His tenure with the Agency lasted over seven years, terminating in January of 1976. In the interim Snepp completed two terms of duty in South Vietnam where, because of the nature of his work, he frequently sought and obtained access to classified information. ${ }^{9}$ Immediately before joining and leaving the CIA, Snepp signed secrecy agreements with his employer. ${ }^{10}$

Highly critical of the manner in which the United States had withdrawn from Vietnam, Snepp decided to publish his views. Even before his resignation became effective, Snepp negotiated with a publisher "whose identity he was assiduous in concealing." 11 A deal was struck and a publication advance was paid.12 Thereafter, as Snepp worked on his book he made no attempt to conceal his undertaking from his former CIA colleagues. ${ }^{13}$ News of Snepp's activity in fact even reached Admiral Stansfield Turner, then Director of Central Intelligence. Turner, relying on provisions of the secrecy agreements Snepp had signed, informed Snepp that he could not publish without prior Agency approval. ${ }^{14}$ Snepp either "assured, or at least lead [sic] . . . Admiral Turner . . . to believe" that he would submit his manuscript for prepublication review. ${ }^{15}$ Consequently the GIA made no attempt to enjoin publication. ${ }^{16}$

8 Communications incident to espionage enjoy no first amendment protection at all. See Haig v. Agee, 453 U.S. 280, 308-09 (1981); United States v. Rosenberg, 195 F.2d 583, 591 (2d Cir.), cert. denied, 344 U.S. 838 (1952).

9 United States v. Snepp, 456 F. Supp. 176, 178 (E.D. Va. 1978), rev'd in part, 595 F.2d 926 (4th Cir. 1979), reinstated, 444 U.S. 507 (1980) (per curiam).

10 Snepp v. United States, 444 U.S. 507, 508 \& n.1 (1980) (per curiam). The texts that Snepp signed at the beginning and end of his employment are reproduced infra at Appendices $A$ and $B$.

11 United States v. Snepp, 595 F.2d 926, 930 (4th Cir. 1979), rev'd in part, 444 U.S. 507 (1980) (per curiam).

$12 I d$.

13 Id.

14 Snepp, 456 F. Supp. at 179.

15 Id.

16 Snepp, 595 F.2d at 930-31. The CIA had previously enjoined another former agent, Victor Marchetti, in United States v. Marchetti, 466 F.2d 1309 (4th Cir.), cert. denied, 409 U.S. 1063 (1972). 
Despite these assurances, Snepp never tendered any drafts to the CIA. Rather, he secretly arranged to expedite publication. ${ }^{17}$ From this point on, Snepp "did everything he could to keep the CIA from knowing about [the book] prior to publication." I8 $\mathrm{He}$ was successful, and his work, Decent Interval, ${ }^{19}$ entered the stream of commerce in November, 1977.20

Decent Interval, the government would later concede for purposes of litigation, contained neither classified information nor any information concerning the CIA that had not previously been made public by the Agency. ${ }^{21}$ Yet, despite the work's non-classified nature,22 the CIA contended that Snepp's willful disregard of his prepublication review covenant had caused the CIA irreparable injury. Snepp's flouting of internal clearance procedures, the CIA asserted, interfered with its efforts to maintain liaisons with friendly foreign intelligence services. ${ }^{23}$ Because these agencies share sensitive information only when assured that the CIA can guarantee the data's confidentiality, it was irrelevant that Snepp did not actually breach confidences; his actions highlighted the possibility of such a breach and consequently diminished foreign trust in CIA reliability. ${ }^{24}$ The CIA therefore filed suit on February 15, 1978, alleging that by simply failing to submit to prepublica-

17 Snepp, 456 F. Supp. at 179. The district court found that Snepp's negotiations with his publisher "were conducted on park benches, in restaurants and/or in the public library." Id.

18 Id. Snepp claimed that he reneged on his "assurances" because the CIA "failed to act favorably . . . on his several demands that it conduct a study and prepare a report concerning the deficiencies in its withdrawal from Vietnam." 595 F.2d at 930 . Senior District Judge Oren R. Lewis concluded, however, that Snepp never intended to submit to prepublication review. $456 \mathrm{~F}$. Supp. at 179 . Judge Lewis based this judgment on the timing and character of Snepp's dealings with his publisher. See supra note 17.

19 F. SNepp, Decent InTERval (1977).

The Fourth Circuit described the book in these words:

It is a highly critical account of the United States' withdrawal from Vietnam at the close of the war and it also contains allegations that the CIA's intelligence reporting from Vietnam was fabricated and distorted, that the CIA manipulated press reporting from Vietnam by providing false information to reporters, that CIA officials in Vietnam engaged in corrupt practices, and that the CIA mishandled the evacuation from

Vietnam by failing to evacuate its indigenous agents and employees.

Snepp, 595 F.2d at 931 .

20456 F. Supp. at 178.

21595 F.2d at 931.

22 Notwithstanding its "benign" content, Decent Interval, one can surmise, was not popular with the CIA high command. See supra note 19.

23456 F. Supp. at $179-80$.

24 Snepp v. United States, 444 U.S. 507, 511-13 (1980) (per curiam). 
tion review Snepp had breached both contractual and fiduciary obligations owed the CIA. ${ }^{25}$ The government sought the following relief: a declaration that Snepp had violated valid contractual and fiduciary duties, an injunction against future breaches, damages for breach of contract, and the imposition of a constructive trust over all revenues, past and future, derived from the commercial exploitation of Decent Interval. ${ }^{26}$

\section{B. The Opinions}

In answering the government's complaint, Snepp put forth numerous affirmative defenses. This Article concentrates on the merits of Snepp's central contention-that the first amendment renders unenforceable any duty to submit to CIA prepublication clearance. ${ }^{27}$ Both the district court and the Fourth Circuit Court of Appeals rejected this argument. Both courts relied on United States v. Marchetti, ${ }^{28}$ an earlier Fourth Circuit decision involving a former CIA agent who, like Snepp, had grown disenchanted with the Agency. In Marchetti, the government sought and obtained an injunction preventing Marchetti from publishing any CIA-related writings without prior CIA scrutiny. Neither court saw any significant difference between Marchetti's position and Snepp's, nor any reason to reexamine the Marchetti decision.

The Supreme Court brushed aside Snepp's contention in even more summary fashion, allotting a mere footnote to the enforceability of the secrecy agreement. First, the 1968 contract was held to be an "entirely appropriate" " 29 method of satisfying the CIA Director's statutory obligation to "protec $[\mathrm{t}]$ intelligence sources and methods." 30 Second, the Court held that "this Court's cases make clear that-even in the absence of an agreement-the CIA could have acted to protect substantial government interests by imposing reasonable restrictions on employee activities that in other contexts might be protected by the First Amendment." 31 Both parts of this test were met. "Compelling" government interests were found in the need to "protec[t] both the secrecy of

25595 F.2d at 931.

$26 I d$.

27 Snepp's other asserted defenses are catalogued in the district court's opinion. Snepp, 456 F. Supp. at 177-78.

28466 F.2d 1309 (4th Cir.), cert. denied, 409 U.S. 1063 (1972). See Snepp, 456 F. Supp. at 180, 595 F.2d at $931-32$.

29 Snepp, 444 U.S. at 509 n.3 (citing the opinion below, 595 F.2d at 932).

3050 U.S.C. $\$ 403(\mathrm{~d})(3)$ (1976).

31444 U.S. at 509 n.3. 
information important to our national security and the appearance of confidentiality so essential to the effective operation of our foreign intelligence service." 32 Snepp's contract, the Justices further concluded, reasonably protected these interests. ${ }^{33}$

In dissent, Justice Stevens, ${ }^{34}$ while refusing to take a definitive position on the issue of enforceability, ${ }^{35}$ approached the problem by analogizing the secrecy agreement to private employeeemployer covenants not to compete. ${ }^{36}$ Justice Stevens began with the proposition that Snepp, like all other employees, was bound by a fiduciary duty not to reveal the confidential, or classified, information of his employer. ${ }^{37}$ The prepublication review clause, like a covenant not to compete, thus became a contractual duty "imposed in aid of the basic duty to maintain confidentiality." 38 As such it was subject to the "rule of reason," and was hence enforceable only to the extent that (1) it was reasonably necessary to protect the CIA's legitimate interest in keeping classified information confidential; (2) the CIA's interest outweighed the public interest in receiving information about public affairs; and (3) the covenant was of no longer duration than was necessary to protect the interest in confidentiality. ${ }^{39}$

In contrast to the truncated discussions of enforceability that appear in the various Snepp opinions, the question of appropriate remedy received considerable attention. Two components of the requested nondeclaratory relief, however, caused little problem as far as the judges and justices were concerned. Given the validity of the contract, no court disputed the CIA's entitlement either to an injunction against future breaches or to contractual damage relief-nominal and compensable. The controversy grew out of the district court's decision to impose a constructive trust on the royalties and proceeds from Decent Interval. ${ }^{40}$ The Fourth Circuit reversed this aspect of the decision, holding Snepp's prepublication review duty to be merely contractual and not fiduciary.

$32 I d$.

33 Id.

34 Justices Brennan and Marshall joined Justice Stevens.

35444 U.S. at 526 n.17 (Stevens, J., dissenting).

36 Id. 519.

37 Id. 518.

$38 I d$.

39 Id. 519. See generally Comment, National Security and the First Amendment: The CIA in the Marketplace of Ideas, 14 HARv. C.R.-C.L. L. Rev. 655, 659-72 (1979).

40456 F. Supp. at 182. 
The constructive trust device, one designed solely to remedy fiduciary breaches, was therefore an inappropriate response. ${ }^{41}$ The court noted further that constructive trust relief was particularly ill-suited to the government's stated purposes-punishing Snepp and deterring others similarly inclined: "a constructive trust depends on the concept of unjust enrichment rather than deterrence and punishment." 42 The proper response, the court reasoned, was to impose punitive damages. ${ }^{43}$ Senior District Judge Walter E. Hoffman, sitting by designation, dissented on this point and voted to uphold the district court's award in its entirety. Snepp's failure to seek prepublication clearance, Judge Hoffman concluded, constituted a breach of fiduciary obligations created both by the terms of the secrecy agreement ${ }^{44}$ and by the nature of CIA employment. ${ }^{45}$ As such, Snepp's breaches formed the appropriate predicate for constructive trust relief.

The Supreme Court agreed with Judge Hoffman. Snepp, the majority argued, had not only failed to observe binding contractual duties, but had breached his "trust" as well. Proof that Snepp had "enter[ed] a trust relationship" was found in the opening provisions of the secrecy agreement itself, ${ }^{46}$ for there Snepp had expressly acknowledged that he was "undertaking a position of trust." 47 As for the actual scope of Snepp's fiduciary obligations, the Court here too found it unnecessary to look beyond the words of the secrecy contract.48 Thus because Snepp had covenanted to submit for prior review all manuscripts containing CIA information, his failure to do so was a fiduciary breach subject to the constructive trust remedy. 49

Justice Stevens disagreed once again. Given Decent Interval's unclassified status, the CIA, he argued, would ultimately have had "to clear the book for publication in precisely the same form as it now stands." 50 Snepp's profits were thus in no way traceable

41595 F.2d at $935-36$.

42 Id. 937 (citation omitted).

43 To obtain the relief, the CIA would have to show on remand that Snepp's breach had been "tortious." 595 F.2d at 936-38.

44 Id. 938 (Hoffman, J., concurring in part and dissenting in part).

45 Id. 939.

40444 U.S. at 510.

47 See Appendix A at para. 1. The Court further noted that even in the absence of the secrecy agreement, "the nature of Snepp's duties and his conceded access to confidential sources and materials could establish a trust relationship." 444 U.S. at 511 n.6 (citation omitted).

48444 U.S. at 515 n.11.

$49 \mathrm{Id} .511$.

50 Id. 521 . 
to his breach. Consequently, "the Government, rather than Snepp, [would] be unjustly enriched if he is required to disgorge profits attributable to his own legitimate activity." 51

Doctrine aside, the majority opinion clearly emanates from a belief that only the threat of a severe sanction adequately insures that former agents will comply with their presubmission obligations. For the justices, normal contract damage relief was not enough. The threat of compensable relief was illusory because "the actual damages attributable to a publication such as Snepp's generally are unquantifiable." 52 Nominal damages were quickly dismissed as "a hollow alternative, certain to deter no one." 53 Even the Fourth Circuit's novel suggestion of punitive relief was insufficient. To obtain such relief the GIA would, under the Fourth Circuit's standards, have to prove to a jury that Snepp's breach of contract had been tortious. ${ }^{54}$ Because such a requirement "might force the government to disclose some of the very confidences that Snepp promised to protect," 55 the punitive option quickly reduced, in the Justices' minds, to "no remedy at all." bs Unstated but assumed was the further belief that prospective injunctions would have little effect, if any, on "first offenders" such as Snepp. A constructive trust was both proper and necessary.

$51 I d$.

52 Id. 514.

63 Id.

$54 I d$

$55 I d$.

56 Id. 515. Why damaging disclosures would have to be made to the jury is never adequately explained. For support, the Court relied solely on a letter written by former CIA Director William E. Colby. Id. Colby's letter, however, only discusses the problems the CIA faces in criminally prosecuting individuals who disclose classified information. See App. to Petition for Certiorari at 68a, Snepp v. United States, 444 U.S. 507 (1980) (per curiam) [hereinafter cited as Colby Letter]. While the Court refers to these problems as "analogous," 444 U.S. at 515, they are not. As discussed more fully later, criminal prosecutions of this sort require proof that the defendant's disclosures harmed national security. See infra text accompanying notes 157-203. As could be expected, this requirement often necessitates further disclosures of sensitive information. See infra text accompanying notes 320-21. But such showings are not called for under the Fourth Circuit's punitive damage doctrine: The CIA need show only that Snepp's breach was accompanied by deceitful, tortious conduct. Relevant here would be proof that Snepp deliberately misled the CIA into believing that he would comply with the presubmission duty and that the CIA relied thereon. See Snepp, 595 F.2d at 936-37. It is hard to see how national security would in any way be compromised in such a proceeding. See Snepp, 444 U.S. at 525 (Stevens, J., dissenting). Clearly the government itself had little fear of seeking punitive relief. Such relief, it contended, was "sufficient in this case to protect the Agency's interest." Id. 524 (citing government's cross-petition for certiorari). 
II. The Scope of the Restraints Imposed by the

\section{SEGRECy Contract}

As has been seen, the Supreme Court in Snepp ${ }^{57}$ upheld against first amendment challenge CIA restraints on the communicative activities of its agents. More specifically, the Court sustained the following covenant:

Inasmuch as employment by the Government is a privilege not a right, in consideration of my employment by CIA I undertake not to publish or participate in the publication of any information or material relating to the Agency, its activities or intelligence activities generally, either during or after the term of my employment by the Agency without specific prior approval by the Agency. . . .58

In reaching its result, the Court read the clause literally, arguing that it requires prepublication submission of any publication containing CIA-related material.59 What subsequent procedure does the clause then contemplate? 60 Can the GIA "review" the manuscript indefinitely?

The Court gave only the briefest guidance as to its conception of the post-submission mechanism. The Fourth Gircuit in United States 7 . Marchetti, however, was much more explicit:

Because we are dealing with a prior restraint upon speech, we think that the CIA must act promptly to approve or disapprove any material which may be submitted to it by Marchetti. Undue delay would impair the reasonableness of the restraint, and that reasonableness is to be maintained if the restraint is to be enforced. We should think that, in all events, the maximum period for responding after the submission of material for approval should not exceed thirty days. ${ }^{61}$

57 Snepp v. United States, 444 U.S. 507 (1980) (per curiam).

58 See Appendix A at para. 8.

59444 U.S. at 508.

60 Secrecy agreement provisions are construed with reference to the "federal common law and not merely the law of a state having some nexus to its formation." United States v. Snepp, 595 F.2d 926, 936 n.10 (4th Cir. 1979), rev'd, 444 U.S. 507 (1980) (per curiam).

61 United States v. Marchetti, 466 F.2d 1309, 1317 (4th Cir.), cert. denied, 409 U.S. 1063 (1972). 
The Snepp Court did not specifically address this question, ${ }^{62}$ but in Freedman $v$. Maryland ${ }^{63}$ the Court ruled that even permissible systems of prior review must be accompanied by procedural safeguards. One requirement Freedman established was that "any restraint prior to judicial review can be imposed only briefly in order to preserve the status quo." 64 As discussed later, even the allowance of only thirty days for CIA review arguably violates this norm. ${ }^{65}$ In light of this fact and in light of the goal of analyzing the CIA's restraints under the most favorable conditions possible, it will hereafter be assumed that the CIA acquiesces in this aspect of Marchetti, and that it neither seeks nor requires a review period of any longer duration.

What then happens at the termination of the thirty-day period? Assume that the CIA completes its review within the allotted time and ultimately concludes that it will not approve publication of certain items. Can the former agent now publish the work in its original form or must he or she first obtain court approval? Marchetti was unambiguous: "Because of the sensitivity of the area and the confidentiality of the relationship in which the information was obtained ... we find no reason to impose the burden of obtaining judicial review upon the CIA. It ought to be on Marchetti." 66 The Snepp Supreme Court disagreed:

If Snepp, in compliance with his contract, had submitted his manuscript for review and the Agency had found it to contain sensitive material, presumably-if one accepts Snepp's present assertion of good intentions-an effort would have been made to eliminate harmful disclosures. Absent agreement in this respect, the Agency would have borne the burden of seeking an injunction against publication. ${ }^{87}$

Once the thirty-day review period ceases, a former agent's speech can be further obstructed only if the CIA takes the initiative and obtains an injunction barring disclosure.

62 Judge Gerhard Gesell nevertheless believes that the thirty-day rule was "endorsed, if not mandated" by the Supreme Court. Agee v. Central Intelligence Agency, 500 F. Supp. 506, 510 (D.D.C. 1980).

63380 U.S. 51 (1965).

64 Id. $61 \mathrm{n}$. (Douglas, J., concurring); id. 58-59 (majority opinion).

65 See infra note 266.

66466 F.2d at 1317.

67444 U.S. at 513 n.8 (citations omitted). The omitted citations refer incorrectly to Alfred A. Knopf, Inc. v. Colby, 509 F.2d 1362 (4th Cir.), cert. denied, 421 U.S. 992 (1975) and Marchetti. 
Under Marchetti, an injunction cannot issue if the former agent intends to reveal only unclassified information ${ }^{68}$ or classified information which has already entered the public domain. ${ }^{69}$ The bona fides of a given classification, however, cannot be disputed. Given the judiciary's institutional inability to review classification decisions, the CIA, under Marchetti, need prove only that an item was classified; it need not additionally show that it was properly classifiable under executive regulations governing classification of information. ${ }^{70}$

This aspect of Marchetti was reversed three years later in Alfred A. Knopf, Inc. v. Colby. ${ }^{71}$ In the interim Marchetti had written a book in collaboration with John Marks, a former State Department employee who had also signed secrecy agreements. In compliance with the Marchetti injunction, the authors submitted their work for prepublication clearance. The CIA initially refused to authorize the release of 339 items, but negotiations reduced this number to 168.72 Marchetti, Marks, and their publisher, Alfred A. Knopf, Inc., then brought suit to compel the release of the remaining deletion items. ${ }^{73}$ The district court released for publication all but 26 items, holding as to the released items that the government had offered insufficient proof of actual classification. ${ }^{74}$ On appeal, the Fourth Circuit first reconsidered its decision to abstain from classifiability determinations. The court noted that, under. recent amendments to the Freedom of Information Act (FOIA), ${ }^{75}$ any private citizen could obtain judicial review of an agency's determination that in-

68 Marchetti, 466 F.2d at 1313, 1317.

Under current classification procedures, material is stamped "Confidential," "Secret," or "Top Secret" depending on its sensitivity. See infra note 161.

In general the classification of government information is governed by criteria promulgated by the President in the form of an Executive Order, which are revised at the discretion of the President. Neither Congress nor the judiciary plays a role in their formation. Cf. New York Times Co. v. United States, 403 U.S. 713, 729-30 (1971) (per curiam) (Stewart, J., concurring) ("[I]t is the Constitutional duty of the Executive -as a matter of sovereign prerogative and not as a matter of law as the courts know law-to protect the confidentiality necessary to carry out its responsibilities in the fields of international relations and national defense.").

69 Id. 1318.

$70 \mathrm{Id}$. 1317-18. Judge Craven, in a concurrence, disagreed with the Marchetti court's \#lat prohibition on inquiries into classifiability. Agents raising classifiability appeals would obtain Judge Craven's vote, however, only if they could "demonstrate by clear and convincing evidence that a classification is arbitrary and capricious . . .." Id. 1318 (Craven, J., concurring).

71509 F.2d 1362 (4th Cir.), cert. denied, 421 U.S. 992 (1975).

72 Id. 1365.

73 They were at that time operating under the Marchetti rule that former agents bear the burden of seeking judicial review.

74 Knopf, 509 F.2d at 1365-67.

755 U.S.C. $\$ 552$ (1976). 
formation was classifiable and hence not subject to disclosure under the FOIA. Secrecy agreement signers, the court concluded, should stand in no worse position:

These plaintiffs should not be denied the right to publish information which any citizen could compel the CIA to produce and, after production, could publish. We thus move to the conclusion that the deletion items should be suppressed only if they are found both to be classified and classifiable under the Executive Order. ${ }^{76}$

The Knopf court defined as well the type of evidence needed to prove actual classification. Relying on "a presumption of regularity in the performance by a public official of his public duty," 7 the court held the CIA's burden of proof discharged by the production of documents bearing classification stamps ${ }^{78}$ and containing the information in question. While acknowledging that not all information in a classified document is sensitive, ${ }^{79}$ the court concluded that

[the] presumption [of regularity] leaves no room for speculation that information which the district court can recognize as proper for top secret classification was not classified at all by the official who placed the "Top Secret" legend on the document. This is so whether or not the document contains or may contain other information which should have been classified in the same degree. Under the prevailing practice of classifying a document in accordance with the most sensitive information it contains, the presumption, in the absence of affirmative proof to the contrary, requires the conclusion that all information within it, required by the Executive Order to be classified, was classified when the legend was affixed to the document ....$^{80}$

Under Knopf, then, information can be suppressed if it appears anywhere in a classified document and meets current ${ }^{81}$ classification standards. ${ }^{22}$

76509 F.2d at 1367.

77 Id. 1368.

78 See supra note 68.

79 Weather information, for example, may appear in secret testing reports. See Knopf, 509 F.2d at 1367.

80 Id. 1368.

81 It must be noted that if secrecy-agreement signers are to have only those rights that the public possesses under the FOIA, the CIA should not bear the burden of showing current classifiability. The Agency should instead have to show 
Dicta in Snepp hinted that the GIA's ultimate censorship power extended further. The prior submission process, the justices asserted, would encompass "an effort ... to eliminate harmful disclosures." 83. The majority, moreover, disagreed with the dissent's description of the common law protection accorded an employer's "confidential" information: "[Justice Stevens] seems to think that the common law would not treat information as 'confidential' unless it were 'classified.' We have thought that the common law obligation was considerably more expansive." 84

But to Justice Stevens, what was most significant was "that the Court does not disagree with the Fourth Circuit's view in Marchetti, reiterated in Snepp, that a CIA employee has a First Amendment right to publish unclassified information." 85 He accordingly did "not understand the Court to imply that the Government could obtain an injunction against the publication of unclassified information." ${ }^{86}$ "[T] $]$ he Government's censorship authority . . . [is] limited," in Justice Stevens' view, "to the excision of classified material." 87 What is perhaps most noteworthy about these passages is that neither the majority nor the dissent once mentions a requirement of classifiability.88 Nevertheless, for purposes of further analysis, it will be assumed that Knopf remains good law. For one thing, no Supreme Court majority has expressly ruled otherwise. For another, courts have no business suppressing information that

only that the data is classifiable under the standards in force at the time of actual classification or reclassification. No more is required under the FOIA. Stein v. United States Dep't of Justice, 662 F.2d 1245, 1256 (7th Cir. 1981); Lesar v. United States Dep't of Justice, 636 F.2d 472, 480 (D.C. Cir. 1980). In order to simplify the analysis, this refinement will largely be ignored. But see infra note 330. It will be assumed that the standards stated in Executive Order 12,356 apply. See infra note 161 .

82 It is unclear whether the CLA can enjoin its former agents from revealing all properly classified information or only that obtained through CIA employment. Compare Knopf, 509 F.2d at 1369 ("we are dealing here ... with information acquired by Marchetti during his employment by the CIA") and Marchetti, 466 F.2d at 1317 ("Marchetti . . may not disclose classified information obtained by him during the course of his employment") with Agee v. Central Intelligence Agency, 500 F. Supp. 506, 510 (D.D.C. 1980) (CIA suppression power not limited to "information learned during employment").

83444 U.S. at 509 n.3, 511-12, 513 n.8 (emphasis added).

84 Id. $515 \mathrm{n} .11$ (citation omitted).

85 Id. 521 n.II (Stevens, J., dissenting).

$86 \mathrm{Id}$.

87 Id. 521.

88 Cf. Agee v. Central Intelligence Agency, 500 F. Supp. 506, 510 (D.D.C. 1980) (commanding the CIA to release for publication only those future submissions that contain no classified information). 
does not even merit protection under the Executive Branch's own standards for nondisclosure. ${ }^{89}$

In sum, secrecy agreements such as Snepp's contemplate the following procedure: Before publication, signers must submit to the CIA all manuscripts containing any CIA-related information. The CIA then has thirty days to complete its review, after which the author is free to publish unless the CIA seeks and obtains an injunction preventing publication. The ClA can obtain an injunction upon a showing that the manuscript reveals information both classified and classifiable. Agents who disregard these duties can be enjoined from future breaches and can be made to answer for both breach of contract and breach of trust.

\section{The Nature of the Restraints Contemplated by the CIA's Secrecy Agreement-Could They Be Imposed Upon All Gitizens?}

\section{A. Presubmission Requirement}

1. Enforced by Subsequent Punishment

Assume that a private citizen publishes without prior Agency clearance a manuscript that discusses CIA activities. Could a court grant a CIA request to punish the citizen's unilateral disclosure? As a preliminary matter, it seems obvious that the government is not entitled in the private citizen context to the type of after-the-fact relief-contract damage and constructive trust liability-sought in Snepp. ${ }^{90}$ The citizen has neither signed a secrecy agreement ${ }^{91}$ nor worked with the CIA in a position of "trust." 92 The theoretical predicates of these two sanctions are therefore lacking. Moreover, no existing statute makes it illegal per se for a private citizen to speak out about the CIA, with or without prior clearance. ${ }^{93}$ Suppose, however, that Congress at

89 See generally Comment, The CIA Secrecy Agreement and the First Amendment, 81 Columbia L. Rev. 662, 685-94 (1981). For a more extended discussion of whether an agent's speech should be suppressible upon mere proof of actual classification, see infra note 329.

90 United States v. Snepp, 456 F. Supp. 176 (E.D. Va. 1978), rev'd in part, 595 F.2d 926 (4th Cir. 1979), reinstated, 444 U.S. 507 (1980) (per curiam).

91 See supra text accompanying notes 5-6.

92 See supra id.

93 But cf. infra text accompanying notes 154-87 for a discussion of whether the revelation of classified and classifiable information is criminal under current law. See also Intelligence Identities Protection Act, Pub. L. No. 97-200, 96 Stat. 122 (1982) (criminalizing disclosure of names of covert CIA agents, even if information is obtained from public records). 
some future point deems it an offense, punishable by fine, prison term, or both, to speak out about the CIA without first complying with the presubmission duties contemplated by Marchetti, ${ }^{94}$ Knopf,95 and Snepp? ${ }^{90}$ Would such a.hypothetical enactment violate the first amendment?

Such a law would constitute a classic "prior restraint":

The clearest form of prior restraint arises in those situations where the government limitation, expressed in statute, regulation, or otherwise, undertakes to prevent future publication or other communication without advance approval of an executive official. Such limitations are normally enforced by criminal prosecution for having published without the required approval, the prosecution being based upon mere failure to obtain approval and not on any issue concerning the content or manner of the publication. ${ }^{97}$

The Supreme Court has often agreed, reaffirming that the battle for free speech was primarily a struggle against administrative censorship. ${ }^{98}$ Any enactment tending to reestablish such power, the Court has accordingly argued, "strikes at the very foundation of the freedom of the press." 99 As a general rule, then, "speech entitled to maximum first amendment protection may not be subjected to a prior clearance procedure with a government agency." 100

To be sure, even before Snepp, the Court had recognized two exceptions to this rule. In Cox $v$. New Hampshire ${ }^{101}$ a unanimous Court sustained against constitutional challenge a statute outlawing all public parades and processions held without a permit. More recently, in Times Film Corp. v. City of Ghicago, ${ }^{102}$ the Court

94 United States v. Marchetti, 466 F.2d 1309 (4th Cir.), cert. denied, 409 U.S. 1063 (1972).

95 Alfred A. Knopf, Inc. v. Colby, 509 F.2d 1362 (4th Cir.), cert. denied, 421 U.S. 892 (1975).

96 Alternatively, the government could ask the judiciary to create a federal common law remedy. See, e.g., United States v. Kearns, 595 F.2d 729 (D.C. Cir. 1979). Such a remedy would, of course, have to withstand first amendment scrutiny at least as stringent as that applied to the hypothetical statute.

97 Emerson, The Doctrine of Prior Restraint, 20 Law \& Contens. PnoBs. 648, 655 (1955).

88 See, e.g., Schneider v. Town of Irvington, 308 U.S. 147, 164 (1939); Lovell v. City of Griffin, 303 U.S. 444, 451 (1938); Grosjean v. American Press Co., 297 U.S. 233,245 (1936).

99 Lovell v. City of Griffin, 303 U.S. at 451.

100 Central Hudson Gas v. Public Service Comm'n, 447 U.S. 557, 581 n.4 (1980) (Stevens, J., concurring); see also Monaghan, First Amendment "Due Process," 83 Harv. L. Rev. 518, 539 (1970).

101312 U.S. 563 (1941).

102365 U.S. 43 (1961). 
upheld a Chicago ordinance under which no film could lawfully be exhibited unless first submitted to the police commissioner "for examination or censorship." ${ }^{103}$ Neither decision supports a view that the hypothetical restraint on all CIA-related speech would be constitutional.

The statute in Cox passed muster only because it limited permit denials to those based solely upon "considerations of time, place and manner," 104 a standard deemed sufficiently limited and objective. The holding was thus consistent with an unbroken line of decisions establishing that a speaker's access to a public forum may not be conditioned on the unbridled discretion of an executive official. ${ }^{105}$ Indeed, just a year before Cox, the Court struck down a system under which the censor's "decision to issue or refuse [a permit] involve[d] appraisal of facts, the exercise of judgment, and the formation of an opinion." 106 Clearly, then, Cox cannot support a CIA review mechanism that is set up precisely so that agency officials can appraise facts, exercise judgment and form opinions as to the classifiability of the information submitted. Determinations of this nature are hardly neutral and objective. ${ }^{107}$

Nor is the Times Film holding of any aid to the CIA: this decision is sui generis. In two subsequent cases, the Court has unequivocally stated that Times Film rests upon a belief that "films differ from other forms of expression." 108 All the Court decided in Times Film was that there is no constitutional right to exhibit publicly every movie at least once. ${ }^{100}$ Extrapolating anything more from this holding is contrary to the Court's own words. The CIA cannot constitutionally prevail on its hypothetical request for relief.

\section{Enforced by an Injunction Directed Towards a Specific Communication}

Assume that the CIA learns that a private citizen intends to publish an article concerning the Agency. Could the government

103 The Court has also indicated that it is hospitable to the notion of licensing commercial speech. See Central Hudson Gas, 447 U.S. at 571; Virginia Pharmacy Bd. v. Virginia Citizens Consumer Council, 425 U.S. 748, 771 n.24 (1976).

104312 U.S. at 575-56.

105 See Cantwell v. Connecticut, 310 U.S. 296 (1940); Schneider v. Town of Irvington, 308 U.S. 147 (1939); Lovell v. City of Griffin, 303 U.S. 444 (1938). 106 Cantwell, 310 U.S. at 305.

107 See infra text accompanying notes 271-79.

108 Freedman v. Maryland, 380 U.S. 51, 60-61 (1965); Bantam Books, Inc. v. Sullivan, 372 U.S. 58,70 n.10 (1963).

109 Times Film, 365 U.S. at 48. 
obtain a decree ordering the citizen to refrain from publishing for thirty days in order to allow the CIA to prescreen the work? If the government can allege and prove nothing more than that the article is "CIA-related," the answer is surely no, for similar relief was sought and denied in New York Times Co. $v$. United States, ${ }^{110}$ the celebrated Pentagon Papers case. There the government sued to enjoin the New York Times and the Washington Post from publishing extracts of a classified forty-seven-volume study entitled "History of U.S. Decision-Making Process on Viet Nam Policy." 111 Complete suppression, however, was not the objective. Rather the government "asked for a temporary restraint solely to permit it to study and assess the impact on national security of the lengthy documents at issue." ${ }^{112}$ In essence, the government requested the same presubmission rights that the CIA asserts in the hypothetical above. The government's failure in New York Times accordingly implies that a rejection of the CIA's request follows a fortiori. If anything, the facts of New York Times were much more sympathetic to the government's request. The materials there in dispute were both classified and related to an on-going war. Thus, if despite these characteristics, information remains immune from injunction, it is hard to see the logic or policy in refusing similar protection to merely "GIA-related" documents.

The reasoning of various members of the New York Times majority, however, arguably leaves the CIA an opening through which to distinguish the adverse precedent. The New York Times Court viewed the government's request for an injunction as an attempt to impose a prior restraint on publication, that is, as an attempt to obstruct the actual rendition of speech as distinguished from an attempt to punish it after the fact. In this respect the Court, at least formally, broke no new ground. Although as noted before, ${ }^{113}$ the term "prior restraint" traditionally refers to administrative licensing schemes, ${ }^{114}$ the Court had "boldly stepped beyond" ${ }^{115}$ this limited vision over four decades earlier in Near $v$. Minnesota ex rel. Olson. ${ }^{116}$ In Near, the Court was confronted with a challenge to a Minnesota statute authorizing state court

110403 U.S. 713 (1971) (per curiam).

111 Id. 714.

112 Nebraska Press Ass'n v. Stuart, 427 U.S. 539, 559 (1976).

113 See supra text accompanying notes 97-109.

114 See Emerson, supra note 97, at 650-52.

115 Pittsburgh Press Co. v. Pittsburgh Comm'n on Human Relations, 413 U.S. 376,390 (1973).

116283 U.S. 697 (1931). 
injunctions against "malicious, scandalous and defamatory newspaper[s], magazine[s] or other periodical[s]." ${ }^{11 \tau}$ The case arose out of the state's successful attempt to enjoin future "malicious, scandalous and defamatory" editions of the Saturday Press, a local publication that had printed both anti-Semitic remarks and allegations of corrupt ties between various gangsters and public officials. The Court held that the injunction imposed a prior restraint ${ }^{118}$ and was consequently void under the first and fourteenth amendments.

Near thus established not only that judicial orders can act as prior restraints, but also that any prior restraint is an especially odious form of restriction on communicative freedom. Chief Justice Hughes quoted-Blackstone for the proposition that " $[t]$ he liberty of the press is indeed essential to the nature of a free state; but this consists in laying no previous restraints upon publications, and not in freedom from censure for criminal matter when published." 119 Modern developments have, of course, modified Blackstone's subsidiary point; as now construed, the prohibitions of the first and fourteenth amendments also constrain the legislative power to punish already completed speech. ${ }^{120}$ But the primary premise-that systems of prior restraint are fundamentally inconsistent with a regime of free speech-has never been seriously questioned.121 "Any system of prior restraints of expression," the Court has often stated, "comes to this Court bearing a heavy presumption against its constitutional validity." 122

The three-paragraph per curiam opinion in New York Times mechanically followed these guidelines. The requested injunction, being in the nature of a prior restraint, triggered the constitutional presumption of invalidity. Asserting without explanation that the presumption had not been rebutted, the Court rendered judgment for the defendants. ${ }^{123}$

$117 \mathrm{Id} .702$.

118 Id. 713-14.

119 Id. 713 (quoting $\dot{W}$. BLAcKstone, Commentartes on tHE LAwS OF ENGLAND 151) (18th ed. 1836) (emphasis in original).

120 See, e.g., Abrams v. United States, 250 U.S. 616, 627 (1919) (Folmes, J., dissenting).

121 See, e.g., Nebraska Press Ass'n v. Stuart, 427 U.S. 539, 556-62 (1976); Lovell v. City of Griffin, 303 U.S. 444, 451-52 (1938); Grosjean v. American Press Co., 297 U.S. 233, 249 (1936).

122 Bantam Books, Inc. v. Sullivan, 372 U.S. 58, 70 (1963); accord, Organization for a Better Austin v. Keefe, 402 U.S. 415, 419 (1971); Carroll v. President of Princess Anne, 393 U.S. 175, 181 (1968). (1963).

123403 U.S. at 714, quoting Bantam Books, Inc. v. Sullivan, 372 U.S. 58, 70 
The concurring opinions delineated the governing analysis in more detail. Justices Black ${ }^{124}$ and Douglas ${ }^{125}$ adopted an abso: lutist position, holding all prior restraints to be invalid. The remaining members of the six-man coalition rejected this view and implicitly embraced Chief Justice Hughes' famous dictum in Near:

The objection has also been made that the principle as to immunity from previous restraint is stated too broadly, if every such restraint is deemed to be prohibited. That is undoubtedly true; the protection even as to previous restraint is not absolutely unlimited. But the limitation has been recognized only in exceptional cases. "When a nation is at war many things that might be said in time of peace are such a hindrance to its effort that their utterance will not be endured so long as men fight and that no Court could regard them as protected by any constitutional right." Schenck v. United States, 249 U.S. 47, 52. No one would question but that a government might prevent actual obstruction to its recruiting service or the publication of the sailing dates of transports or the number and location of troops. ${ }^{126}$

The Pentagon Papers case provided the Court with its first chance to delineate the contours of the "national security" exception that Chief Justice Hughes had postulated. Hewing close to the language of Near, Justice Brennan stated that he would uphold an injunction only upon "governmental allegation and proof that publication must inevitably, directly, and immediately cause the occurrence of an event kindred to imperiling the safety of a transport already at sea." ${ }^{127}$ Justice Stewart, joined by Justice White, set a similar standard, holding injunctive relief available only upon proof "that disclosure . . . will surely result in direct, immediate, and irreparable damage to our Nation or its people." 128 Five members of the Court thus agreed that, at the very least, extraordinary showings must be made before national security concerns can warrant prior suppression. So imposing was the burden placed on the government that several justices noted that even criminally punishable speech could conceivably retain its immunity

124 Id. 715 (Black, J., concurring).

125 Id. 720 (Douglas, J., concurring).

126 Near, 283 U.S. at 715-16 (footnote omitted).

127 New York Times, 403 U.S. at 726-27 (Brennan, J., concurring).

128 Id. 730 (Stewart, J., concurring). 
from injunction.129 $A$ fortiori, mere proof that a manuscript "relates to" the CIA cannot be sufficient to lift the protection. ${ }^{130}$

The CIA's position may be strengthened, however, by an additional strand of analysis that weaves its way through the words of the New York Times majority. To Justice Marshall, "[t]he issue [was] whether this Court or the Congress has the power to make law." 131 Arguing that Congress had twice refused to render the conduct engaged in by the defendants explicitly unlawful, ${ }^{132}$ Justice Marshall contended that it would "be utterly inconsistent with the concept of separation of powers for this Court to use its power of contempt to prevent behavior that Congress has specifically declined to prohibit." ${ }^{133}$ Justice White's separate opinion, in which Justice Stewart joined, sounded analogous "separation of powers" tones. He found the government's proferred proof insufficient in light of "the heavy burden that it must meet to warrant an injunction against publication in these cases, at least in the absence of express and appropriately limited congressional authorization for prior restraints in circumstances such as these." 134 Thus several members of the Court found significance in the institutional question-whether "the courts and the Executive Branch can 'make law' without regard to the action of Congress" 135

129 Justice Stewart, for example, believed that although the government could not enjoin publication of the Pentagon Papers, it might be able to convict those responsible for its distribution. "[S] leveral of [the Espionage Statutes] are of very colorable relevance to the apparent circumstances of these cases." Id.; accord, id. 733 (White, J., concurring) ("failure by the Government to justify prior restraints does not measure its constitutional entitlement to conviction for criminal publication").

130 The CIA might argue that all CIA-related speech inherently threatens the requisite danger. Cf. id. 754 (Harlan, J., dissenting) ("In order to decide the merits of these cases properly," the Court would have to face the question "[w]hether the threat to publish highly secret documents is of itself a sufficient implication of national security to justify an injunction on the theory that regardless of the contents of the documents harm enough results simply from the demonstration of such breach of secrecy."). Thus far, however, the Agency has claimed that CIA-related speech is injurious per se only if it is engaged in by current or former agents who fail to obtain prior clearance. See Snepp v. United States, 444 U.S. 507 (1980) (per curiam). The serious defects present in this more limited claim, see infra text accompanying notes $302-07$, render any broader contention completely untenable.

131 New York Times, 403 U.S. at 741 (Marshall, J., concurring).

132 Id. 746-47.

${ }^{133} \mathrm{Id} .742$.

134 Id. 731 (White, J., concurring) (emphasis added).

135 Id. 742 (Marshall, J., concurring). Justice Stewart similarly noted that "in the cases before us we are asked neither to construe specific regulations nor to apply specific laws." Id. 730 (Stewart, J., concurring). Justice Black also recognized that "[t]he Government does not even attempt to rely on any act of Congress." Id. 718 (Black, J., concurring). 
posed by the case. By answering this question in the negative, the institutionally oriented concurring opinions conceivably limit the applicability of the substantive standards set forth by Justices Brennan and Stewart. Future plaintiffs such as the CIA have at their disposal the argument that the rigorous standards enunciated in New York Times apply only when congressional authorization for injunctive relief is missing. ${ }^{136}$

This theory finds some support in the recent district court decision in United States $v$. Progressive, Inc. ${ }^{137}$ In Progressive, the United States sought to enjoin publication of a magazine article entitled, "The H-Bomb Secret-How We Got It, Why We're Telling It." As its title implies, the manuscript detailed the design and operation of thermonuclear weapons. In the process, the government alleged, it revealed as well "Restricted Data" 138 as defined by the Atomic Energy Act. ${ }^{139}$ Disclosure of such information under these circumstances being criminal, ${ }^{140}$ the injunctive request fell squarely within the language of 42 U.S.C. $\$ 2280$, which provides that "upon a showing ... that such person has engaged or is about to engage in any . . . acts or practices" violative "of any provision of this chapter," a "permanent or temporary injunction, restraining order, or other order may be granted." ${ }^{141}$

Because the Progressive court concluded that release of the article would result in "direct, immediate and irreparable injury," 142 suppression was consistent with the substantive standard announced by Justice Stewart in New York Times. It was thus unnecessary for the court to decide whether section 2280 was constitutional, that is, whether Congress is empowered to lower the bar against prior restraints by authorizing injunctions upon mere proof of impending statutory violation. Nevertheless, the court reached out to hold that " $[\mathrm{t}]$ he pertinent provisions of the Atomic Energy Act, 42 U.S.C. $§ 2274$ (b) and $\S 2280$, apply to the defendants and are not constitutionally vague or over broad." 143

136 See Cox, supra note 2 , at 7.

137467 F. Supp. 990 (W.D. Wis.), appeal dismissed mem., 610 F.2d 819 (7th Cir. 1979).

138 See 42 U.S.C. $\$ 2014(y)(1976)$.

13942 U.S.C. $\$ \oint 2011-2282$ (1976).

140 See 42 U.S.C. $\$ 2274$ (b) (1976).

14142 U.S.C. $\$ 2280$ (1976).

142467 F. Supp. at 1000.

143 Id. The district court's decision was appealed to the Seventh Circuit, but before that court could act, the government withdrew from the case. Its withdrawal resulted from the fact that several newspapers had in the interim published articles similar to the one The Progressive had wished to run. The underlying data, 
Progressive might thus be read to hold that it is constitutionally permissible for Congress to authorize injunctions against criminal speech even when such speech does not threaten "direct, immediate and irreparable" harm. ${ }^{144}$ Whether or not the Progressive court was correct in granting the legislature this latitude ${ }^{145}$ it should be clear that when first amendment freedoms are implicated, Congress certainly has no greater power. Congress cannot authorize the prior suppression of speech that the constitution immunizes from subsequent punishment. ${ }^{146}$ To conclude otherwise would be to stand Blackstone on his head. ${ }^{147}$

The building blocks of any possible GIA attempt to distinguish New York Times (in the context of restraining private citizens) can now be outlined. First, the Agency must find a statute that renders criminal the citizen's contemplated actions. The Agency must then locate a Congressional enactment authorizing injunctions against the crime. Finally, the CIA must de-

it appears, had always been open to public inspection in the Atomic Energy Commission's own library. See Dworkin, Is the Press Losing the First Amendment?, N.Y. Rev. of Books, Dec. 4, 1980, at 49.

144 Another reading is also possible. Since the court in essence found that the Progressive could have been enjoined under an undeniably constitutional law (one that authorized injunctions only upon proof of "direct, immediate and irreparable" harm), the Progressive had standing to challenge the overbreadth of section 2280 only on its face, not as applied. In upholding the law, the court might thus have been reasoning that while section 2280 was indeed unconstitutional in certain instances, those instances were not sufficiently numerous to support a finding of facial invalidity. Broadrick v. Oklahoma, 413 U.S. 601, 615 (1973) (laws are facially overbroad only if the amount of overbreadth is "not only . . . real, but substantial as well, judged in relation to the statute's plainly legitimate sweep"). It is conceivable, in other words, that the court might have sustained an "as applied" challenge had the Progressive been able to mount one, i.e., if the Progressive had attempted to publish information which, though criminal, was not suppressible under New York Times.

145 See infra note 210 for a discussion of this question.

146 Before it is known whether or not speech is "protected" from subsequent sanction, it can, of course, be subjected to temporary restraining orders which are needed to preserve a court's jurisdiction to decide the issue. See, e.g., New York Times Co. v. United States, 403 U.S. 942 (1971) (restraining order, imposed by court of appeals, continued pending decision); cf. Kingsley Books,' Inc. v. Brown, 354 U.S. 436, 440 (1957) (authorizing state courts to enjoin pendente lite the sale of allegedly obscene books). The temporary restraining order cannot, however, be procured ex parte except under the most exigent of circumstances. See Carroll v. President of Princess Anne, 393 U.S. 175 (1968).

147 See supra note 119 and accompanying text. Justice Brennan apparently disagrees. In New York Times he wrote: "[T]here is no question but that the material sought to be suppressed is within the protection of the First Amendment; the only question is whether, notwithstanding that fact, its publication may be enjoined for a time because of the presence of an overwhelming national interest." 403 U.S. at 726 n. (Brennan, J., concurring) (emphasis added); accord, Brown v. Glines, 444 U.S. 348, 364 (1980) (Brennan, J., dissenting). This viewpoint is completely ahistorical. 
velop a theory that justifies Congress in lowering the New York Times standard.

The GIA can neither find nor construct the necessary first "building block." It has been shown in subsection A.1. above both that the citizen's contemplated behavior is not currently criminal and that it could not constitutionally be deemed such. ${ }^{148}$ The injunctive relief sought in the hypothetical is therefore unavailable. ${ }^{149}$

\section{Enforced by an Injunction Directed Towards Future, Unascertained Communications}

Assume now that a private citizen actually publishes without prior clearance a manuscript that discusses CIA activities. Can the CIA obtain a decree that forbids such behavior in the future and that orders the citizen to submit all future CIA-related works to prior review? Once again the answer is no. Given that the CIA cannot predict the content of the future works, it is impossible for the Agency to surmount the New York Times barrier. Clearly one cannot prove that publication will lead to "direct, immediate, and irreparable damage" 150 when one does not even know what information will be revealed. As one commentator has noted, proof of such damage is extremely difficult even when knowledge of contents is available:

Accurate forecasts of such future events as breakdown in delicate negotiations may well be impossible even given the most favorable combination of credible witnesses and comprehensive intelligence reports. The claim of causa-

148 See supra text accompanying notes 90-109.

149 This entire discussion has been predicated on the notion that the CIA can distinguish New York Times only by stressing the statutory authorization issue. One other distinction might be plausible. The Pentagon Papers case after all involved the rights of the institutional press. One could argue that the holding should be restricted to this fact pattern, that the extraordinary showings the Court majority demanded were imposed solely to protect the press, not individual citizens. See Henkin, The Right to Know and the Duty to Withhold: the Case of the Pentagon Papers, 120 U. PA. L. Rev. 27I, 276 (1971); cf. New York Times, 403 U.S. at 731 n.1 (White, J., concurring) (prior restraints authorized by National Labor Relations and Federal Trade Commission Acts distinguished partly on the basis that "those enjoined ... are private parties, not the press"); but cf. Houchins v. KQED, Inc., 438 U.S. I (1978) (press has no greater right of access to information than does general public). Yet even assuming that this is true, one is still left to a determination of what constitutes the appropriate standard for judging injunctions against mere "individual citizens." Such an analysis must in turn lead once again to the conclusion that private communicative behavior cannot be enjoined unless it is at least subject to subsequent punishment. The lack of this predicate stymies as before any CIA attempt to distinguish New York Times.

150 New York Times, 403 U.S. at 730 (Stewart, J., concurring). 
tion leading to diplomatic decisions is simply too complex to permit the isolation of the impact of a single discrete event such as the publication of the Viet Nam study. ${ }^{151}$

$A$ fortiori, "accurate forecasts" become completely impossible when one cannot even describe the feared "discrete event."

Nor can New York Times be any more successfully distinguished than in section two above. As has been shown, success in this respect depends upon a demonstration that the citizen intends to engage in behavior that lacks constitutional immunity from subsequent punishment. This showing can no more be made here than before. ${ }^{152}$

\section{B. Duty to Abstain Completely from Revealing CIA-Related Information That Is Both Classified and Classifiable ${ }^{153}$}

\section{Enforced by Subsequent Punishment}

In this hypothetical, a private citizen has revealed CIA-related information that is both classified and classifiable. The government seeks to fine or imprison the citizen, arguing that proof of the above factors alone is sufficient. ${ }^{154}$

The prosecution has now escaped the strictures of prior restraint analysis. The government seeks neither prior judicial suppression of speech nor the enforcement of legislative licensing laws. The request is a "mere" demand for subsequent sanction. But the government still must find a statutory basis for punishment, and "contrary to what may well be a popular misconception, the United States does not have an 'Official Secrets Act' making it generally unlawful to disclose classified information." 155 Rather, the United States Code contains numerous and diverse provisions that criminalize specific types of disclosures. ${ }^{156}$ Most relevant for present purposes, and perhaps the broadest of these provisions, is 18 U.S.C. $\$ 793(\mathrm{e})$, which states in pertinent part:

Whoever having unauthorized possession of, access to, or control over any .... information relating to the national

151 The Supreme Court, 1970 Term, 85 Harv. L. Rev. 3, 201 (1971).

152 See supra text accompanying note 148.

153 See supra note 68 for a discussion of these terms.

154 Once again, the theoretical predicates of contract and constructive trust liability, the particular forms of after-the-fact relief sought in Snepp, are missing. The government must rely either on statutory enactment or on federal common law relief. See supra notes $90-92$ and accompanying text.

155 Nimmer, National Security Secrets v. Free Speech: The Issues Left Undecided in the Ellsberg Case, 26 STan. L. Rev. 311, 313 (1974) (footnote omitted). 156 See, e.g., 18 U.S.C. $\$ \$ 792-99$ (1976); 42 U.S.C. $\$ 2274$ (1976). 
defense which information the possessor has reason to believe could be used to the injury of the United States or to the advantage of any foreign nation, willfully communicates, delivers, transmits ... to any person not entitled to receive it . . . [s] hall be fined not more than $\$ 10,000$ or imprisoned not more than ten years or both..$^{157}$

Convictions under section 793(e) thus require proof of five elements: (1) the disclosed information must be defense-related; the defendant must act with sufficient scienter, both (2) with regard to the effect of communicating the information ("reason to believe") and (3) with regard to the act of communicating ("willfully"); (4) the defendant must in fact communicate, deliver, or transmit the data; and (5) the recipient must not be "entitled" to the information. The question presented is whether this five-fold test is satisfied by proof that the defendant has revealed information that is CIA-related, classified and classifiable.

Information that is CIA-related is clearly "relate[d] to the national defense." In Gorin v. United States, ${ }^{158}$ the Supreme Court construed "national defense" to be "a generic concept of broad connotations, referring to the military and naval establishments and the related activities of national preparedness." ${ }^{159}$ Such an expansive definition must certainly encompass information concerning "that Agency of the Government responsible to the President and the National Security Council for intelligence relating to the security of the United States of America." 160

The CIA might next argue that the requisite "reason to believe" is shown by proof of classifiability, since under current Executive Order, information merits classification if unauthorized disclosure "reasonably could be expected to cause damage to the

15718 U.S.C. $\$ 793(e)$ (1976). Justices White, Marshall and Harlan, writing in New York Times Co. v. United States, 403 U.S. 713 (1971) (per curiam), indicated that $\$ 793(e)$ might apply to the Times and the Washington Post if they were to publish the contested information. See id. 737-40 \& n.9 (White, J., concurring); id. 745 (Marshall, J., concurring); id. 754 (Harlan, J., dissenting).

Other parts of $\$ 793$ (e) criminalize the failure to surrender certain government documents. It will be assumed for the purposes of this discussion that the information at issue is not in the form of documents over which the government could assert a proprietary interest.

158312 U.S. 19 (1941).

159 Id. 28. The Gorin Court had before it the predecessors of 18 U.S.C. $\$ \$ 793(\mathrm{~b}), 794(\mathrm{a})$, not section 793(e). All three provisions, however, were originally enacted as components of the Espionage Act of 1917. It is thus unlikely that the meaning of "national defense" varies from section to section.

160 See Appendix A at para. 1. 
national security." 161 Equating classifiability with statutory "reason to believe," however, is erroneous, for while both tests require projections of what is "reasonable," the foci of their inquiries differ. Under the statutory test, a court must zero in on what "the possessor," that is, the private citizen defendant, had reason to believe. ${ }^{162}$ A search for classifiability, by contrast, is much broader. Here, background information unknown to the defendant becomes relevant, for the question presented is not whether the defendant should have known that the information was sensitive, but rather whether a government official with "original classification authority" ${ }^{163}$-the delegation of which is limited to those with a "demonstrable and continuing need" to classify documents ${ }^{164}$-has reason to believe that the information presents a danger. ${ }^{165}$ As a result, a private citizen defendant may often have no reason to believe that any harm will flow from revealing information which later turns out to be classifiable. "What may seem trivial to the uninformed, may appear of great moment to one who has a broad view of the scene and may put the questioned item of information in its proper context." 166

Similarly, it is hard to see how the CIA can discharge its burden of proving "willfulness." Two scholars, following an exhaustive review of the espionage statutes, have argued that "conduct is not willful for purposes of the section, when undertaken for any of the

161 Exec. Order No. 12,356, \$1.1(a)(3), 47 Fed. Reg. 14,874, 14,875 (1982), revoking Exec. Order No. 12,065, 3 C.F.R. \$190 (1979). Information meeting the standard set out in the text" warrants a "Confidential" designation. If the unauthorized disclosure of information can "reasonably . . . be expected to cause serious damage to the national security," a "Secret" label is appropriate. Id. $\$ 1.1(a)(2)$. The highest designation, "Top Secret," applies to information whose unauthorized disclosure can "reasonably . . . be expected to cause exceptionally grave damage to the national security." Id. $\$ 1.1(\mathrm{a})(\mathrm{I})$. Seventy-five percent of all classified information is classified "Confidential." See Chicago Tribune, Oct. 22, 1981 , at 1 , col. 6 .

Under President Carter's prior Executive Order, information could be classified as "Confidential" only if its unauthorized disclosure could "reasonably . . . be expected to cause identifiable damage to national security." Exec. Order No. 12,065, I-302, 3 C.F.R. $\$ \$ 190,193$ (1979) (emphasis added). The conclusions drawn in this Article would be the same even if the "identifiable" requirement still governed.

162 See S. Rep. No. 427, 80th Cong., Ist Sess. 4 (1949); H.R. Rep. No. 1895, 81st Cong., 2d Sess. 1 (1950); cf. Gorin, 312 U.S. at 27-28 (construing predecessor to $\$ 793(\mathrm{a})$ ); United States v. Enger, 472 F. Supp. 490 (D.N.J. 1978) (construing $\S 793(\mathrm{a}))$.

163 Exec. Order No. 12,356, $§ 1.2(d)(1), 47$ Fed. Reg. 14,874, 14,875 (1982). 164 Id.

165 Id. \$ I.1.

166 United States v. Marchetti, 466 F.2d 1309, 1318 (4th Cir.), cert. denied, 409 U.S. 1063 (1972). 
variety of reasons-stimulating public debate, satisfaction of individual curiosity, or conducting private policy discussions-that reflect interests protected by the first amendment." 187 This conclusion derives from "the clear message of the ... legislative histor[y] that publication of defense information for the purpose of selling newspapers or engaging in public debate is not a criminal act." 168 What the statute requires, under this view, is proof of bad motive, proof of an actual intent to harm United States interests. If this construction is correct, the CIA's case in the hypothetical certainly must fail, for proof of motive nowhere appears.

Only one district court has ever opined on the contours of section 793(e) "willfulness," and it rejected this interpretation. ${ }^{169}$ Still, there is much to be said for the suggested theory, for without a motive requirement, the statute is very probably overbroad.170 If motive is irrelevant, section 793(e) criminalizes all unauthorized defense-related communications, even if made solely in the reasonable belief that the disclosure will aid a foreign ally. Judge Learned Hand, writing for the Second Circuit in United States v. Heine, ${ }^{171}$ perhaps best summed up the absurdity of such a prohibition:

If the words mean that, it would be criminal to send to a subject of Britain or to a citizen of France a railway map, a list of merchant ships, a description of automobile assembly technique, an account of the latest discoveries in antisepsis, or in plant or animal breeding, or even a work upon modern physics, provided only the sender had reason to believe that the information might reach the government, and be helpful to it in any of its activities. ${ }^{172}$

Similar concerns about overbreadth have surfaced elsewhere, and, as a result, narrowing constructions have progressively reduced the scope of various espionage law provisions. In Gorin v. United

107 Edgar \& Schmidt, The Espionage Statutes and Publication of Defense Information, 73 CoLUM. L. REv. 929, 1046 (1973).

168 Id. 1001-02.

${ }^{169}$ See United States v. Coplon, 88 F. Supp. 910, 911 (S.D.N.Y. 1949). It is worth noting that the defendants in Coplon were convicted of selling information to agents of a foreign government. They did not assert, nor could they have, a purpose to publish the information and stimulate public discussion of defense issues. One would want a willfulness requirement to distinguish between these two situations. See Edgar \& Schmidt, supra note 167, at 1044-45.

170 Vagueness challenges may be foreclosed by Gorin v. United States, 312 U.S. 19 (1941). But see Edgar \& Schmidt, supra note 167, at 1043.

171151 F.2d 813 (2d Cir. 1945), cert. denied, 328 U.S. 833 (1946).

172 Id. 815 . 
States, ${ }^{173}$ the Supreme Court stated that 18 U.S.C. $\$ 794(a){ }^{174}$ did not apply to the disclosure of information that had been "published by authority of Congress or the military departments." 175 Judge Hand in Heine extended this exemption to private sector information whose distribution the government had not attempted to curtail. ${ }^{178}$ Together, Gorin and Heine thus removed from the purview of section 794(a) all disclosures of information that had previously entered the public domain. ${ }^{177}$ More recently, in United States $v$. Dedeyan, ${ }^{178}$ an overbreadth challenge was brought by a defendant charged with failing to report, in violation of 18 U.S.C. $\S 793(f)(2)$, the abstraction of a document "relating to national defense." 179 The district court instructed the jury that a conviction was warranted only if the state could prove that the disclosed information was secret and that its disclosure was either "potentially damaging to the national defense" or "useful to an enemy of the United States." 180 The Fourth Circuit held that the lower court's instructions cured the problem of overbreadth. ${ }^{181}$

Section 793(f)(2), however, does not criminalize speech. The Dedeyan court's conclusion is thus not authority for the proposition that an identical jury instruction on willful communication would render section 793(e) constitutional. Furthermore, neither the author of Gorin ${ }^{182}$ nor the author of Heine ${ }^{183}$ viewed his narrow statutory construction as a remedy for all problems that might arise in the interpretation of other espionage statutes. And, at least as regards section 793(e), more drastic relief is needed; even if one incorporates all three of the Gorin, Heine and Dedeyan restrictions into the statute, problems of overbreadth remain. The statute would still criminalize a well-meaning revelation of secret (e.g., improperly classified) information if the disclosure reasonably

173312 U.S. 19 ( 1941 ).

174 This provision outlaws pure espionage activities, i.e., transmissions of defense-related information directly to a foreign government.

175312 U.S. at 28.

176151 F.2d at 816.

177 Compare United States v. Progressive, Inc., 467 F. Supp. 990, 993 (W.D. Wisc.), appeal dismissed mem., 610 F.2d 819 (7th Cir. 1979) (the synthesis of already public information may be grounds for prior restraint).

178584 F.2d 36 (4th Cir. I978).

179 I8 U.S.C. $\$ 793$ (f) (1976).

180584 F.2d at 39 (emphasis added).

181 Id. 40.

182 Justice Reed's comments in Gorin were somewhat gratuitous. No formal overbreadth challenge was registered by the petitioners.

183 Judge Hand made clear that he had limited the statute's reach only so far as was needed "in the case at bar." 151 F.2d at 816. 
threatened aid to an "enemy," but not injury to the United States. ${ }^{184}$ Yet, "if a communication does not work an injury to the United States, it would seem to follow logically that no government interest can be asserted to overcome the first amendment's guarantee of freedom of speech." 185

If a defendant acts "willfully," however-that is, specifically intending to injure U.S. interests-the constitutional calculus changes. Now the fact that only "aid" and not "injury" was threatened is perhaps best viewed as a fortuity. By definition, a defendant who acts "willfully" wishes to cause "injury"; only some unexpected intervening factor (perhaps a lack of knowledge of what is truly injurious) prevents this result. Moreover, if not stopped now, the defendant will presumably try again. And if that attempt fails and there is still no punishment, he or she is likely to keep on trying until injury results. Surely the first amendment cannot tie the state's hands to such an extent that it must wait for the defendant to hit the mark before it can act. If he state can prove "willfulness," it should be able to punish the speaker and thereby silence a known threat. ${ }^{186}$

Section 793(e), in sum, avoids the pitfalls of overbreadth only if construed to require proof of bad motive. A showing that the defendant has merely published information that is CIA-related, classified and classifiable should therefore fail. ${ }^{187}$

But could the CIA attain more success with a more narrowly drawn statute? 188 In the analysis above, section 793(e) encountered overbreadth problems solely because it attempted to criminalize

184 Aid to an enemy invariably equals injury to the U.S. only in a zero-sum world, and it is doubtful that ours is such a world.

$185 \mathrm{Nimmer}$, supra note 155, at 330 (footnote omitted).

186 See Haig v. Agee, 453 U.S. 280, 308-09 (1981) ("Agee's disclosures, among other things, have the declared purpose of obstructing intelligence operations and the recruiting of intelligence personnel. They are clearly not protected by the Constitution.").

187 If the hypothetical speaker has utilized the mass media, $\$ 793(\mathrm{e})$ may be inapplicable for an independent reason: the statute's proscription of "communicat[ing], deliver[ing] and transmit[ting]" arguably does not bar "publishing." New York Times Co. v. United States, 403 U.S. 713, 720-22 (1971) (Douglas, J., concurring); United States v. New York Times Co., 328 F. Supp. 324, 328 (S.D.N.Y.), aff'd per curiam, 403 U.S. 713 (1971). See also Developments in the Law-The National Security Interest and Civil Liberties, 85 HARv. L. Rev. 1130, 1238 (1972) [hereinafter cited as Developments]; but see Edgar \& Schmidt, supra note 167, at 1034.

188 Even if the hypothetical speaker can be regulated by a more narrowly drawn statute, he or she still has standing to mount a facial overbreadth challenge to a prosecution under $\$ 793(\mathrm{e})$. Cf. NAACP v. Button, 371 U.S. $415,432-33$ (1963) (petitioner allowed to challenge barratry statute regardless of "whether... the petitioner has engaged in privileged conduct"). 
noninjurious speech. It was assumed, for the purposes of analysis, that no additional problems were presented by its treatment of injurious disclosures. ${ }^{189}$ But what if Congress were to pass a law simply proscribing all communications of properly classifiable information, that is, those that can reasonably be expected to cause at least some damage to national security? ${ }^{190}$ The constitutionality of the more limited restraint would then have to be faced.

The most instructive precedent is Landmark Communications, Inc. v. Virginia. ${ }^{191}$ At issue in that case was a Virginia statute that criminalized all comment about the confidential proceedings of the state judicial review commission. Although willing to assume that the statute was constitutional as applied against commission "participants," 192 the Court nevertheless overturned the conviction of a newpaper that had published information about a pending inquiry. Third-party speech, the Court held, could be punished only upon proof that it had threatened a "clear and present" danger to the effectuation of legitimate state goals. ${ }^{193}$ Mere proof that the disclosed information had been labelled "confidential" by the state was insufficient. Landmark accordingly stands for the general proposition that even when the state has a right to refuse disclosure of a given piece of information, ${ }^{194}$ once a private citizen obtains it in some manner, ${ }^{195}$ further dissemination by that citizen can be outlawed only upon extraordinary showings. More specifically, the state must show that the citizen's speech threatens a substantive evil that is "extremely serious" and whose "degree of imminence [is] extremely high." 196 The danger, in short, must be both "clear" and "present."

189 More precisely, it was assumed that even if any overbreadth inhered in the "injury of the United States" clause, it was necessarily cured by any construction that saved the more troubling "advantage of any foreign nation" language.

190 See supra note 161 and accompanying text.

191435 U.S. 829 (1978).

192 Id. 837 \& n. 10 .

193 Id. 842-46.

194 Landmark made no claim that it had a constitutional right of access to the information. Id. 837 .

195 It is apparently irrelevant that the data is procured as the result of a criminal transaction. Only a person with access, namely a "participant," could have provided Landmark with its information. All sides agreed that such a disclosure was criminal. See generally Cox, supra note 2, at 11-12. Professor Cox has argued that it might be proper to recognize an exception to this approach when the third party does not simply receive confidential information passively, but instead "knowingly and actively induce[s]" the criminal act itself. Id. 12.

196435 U.S. at 845 (quoting Bridges v. California, 314 U.S. 252, 263 (1941)). 
The hypothetical statute postulated above must be tested against these principles. It is thus irrelevant that a private citizen has no enforceable right to obtain classifiable data. ${ }^{197}$ Once obtained, ${ }^{198}$ dissemination rights are limited only to the extent that the state can show the presence of a "clear and present" danger, ${ }^{109}$ a standard not met by mere proof of classifiability; not all disclosures of classifiable information inevitably threaten "extremely serious" dangers. ${ }^{200}$ Moreover, the required degree of imminence is not satisfied by proof of classifiability. Harms flowing from classifiable revelations need only be "reasonably expected." 201 Thus if the government wishes to punish our hypothetical citizen, and if it wishes as well to avoid the burden of proving bad motive, it

197 Properly classifiable information is exempt from the disclosure requirements of the Freedom of Information Act. See 5 U.S.C. $\$ 552(\mathrm{~b})(1)$ (1976).

Until recently, however, the public may have had some rights vis-d-vis classifiable data. Executive Order 12,065 recognized that "the need to protect such information may be outweighed by the public interest in disclosure of the information. . . " Exec. Order No. 12,065, $\$ 3-303,3$ C.F.R. 190, 197 (1979). Thus "[w] hen such questions [arose]," declassifying officers were required to balance the public's right to know against the harms of disclosure. Id. If the balance favored the public, "the information should [have been] declassified," notwithstanding the fact that it still merited classification. Id. President Reagan's new Executive Order eliminates the "public interest" balancing requirement. Exec. Order No. 12,356, 47 Fed. Reg. 14,874 (1982).

Yet even under Executive Order 12,065, the public's "right" to classifiable information was very speculative. FOIA courts had held that they could order governmental units to balance; the question of when "questions [arose]" was not an issue committed solely to Agency discretion. See Navasky v. Central Intelligence Agency, 499 F. Supp. 269, 275-76 (S.D.N.Y. 1980); Kanter v. Dep't of State, 479 F. Supp. 921 , 923 n.3 (D.D.C. 1979). Administrative determinations of how the balance tilted, however, were not subject to judicial review. The FOIA court's jurisdiction was limited to determining whether the information was classifiable, and how the balance came out was not relevant to this point. See Navasky, 499 F. Supp. at 275; but see Allen v. Central Intelligence Agency, 636 F.2d 1287, 1293 n.34 (D.C. Cir. 1980) (dictum); see generally, Halperin, A Balancing Test for Classified Information, 38 FED. B.J. 134 (1979).

It is indeed fortunate that "extremely serious" dangers do not always accompany disclosures of classifiable information, given the rate at which they occur. See Halperin, supra.

198 Even if Professor Cox's suggested modification to the principle listed supra at note 195 is accepted, the CIA's position is not advanced in the hypothetical. Mere evidence that a speaker has disclosed CIA-related data that is classified and classifiable does not establish that the speaker initially obtained this information by inducing a CIA "insider" to breach security.

100 The "clear and present danger" standard has been applied in the past in the national security context. Schenck v. United States, 249 U.S. 47, 52 (1919) (Holmes, J.).

200 To be classifiable, information need only have the potential to cause some damage if disclosed. See supra note 161. See also supra note 197.

201 See supra note 161 and accompanying text. 
must show more than mere classifiability. ${ }^{202}$ It must show more than it has done in the hypothetical. ${ }^{203}$

\section{Enforced by an Injunction Directed Towards a Specific Communication}

In this scenario, the government learns that a private citizen intends to disseminate CIA-related information that is both classified and classifiable. The question presented is whether the government is entitled to an injunction completely barring the dissemination.

The government's request must once again be denied. The Pentagon Papers themselves were classified, ${ }^{204}$ but this factor alone did not establish the government's right to even temporary injunctive relief. Nor is added proof of "classifiability" sufficient under New York Times. Under Executive Order 12,356, information is classifiable if the state can show that its unauthorized disclosure can "reasonably... be expected to cause damage to the national security." 205 Such a showing hardly satisfies Justice Brennan's demand for "proof that publication must inevitably, directly and immediately cause the occurrence of an event kindred to imperiling the safety of a transport already at sea." 206 Similarly such a showing fails to satisfy Justice Stewart's requirement that disclosure "surely result in direct, immediate, and irreparable damage." 207 The availability of injunctive relief in the hypothetical thus once again depends upon successfully distinguishing New York Times. ${ }^{208}$ As shown in subsection III.A.2. above, this in turn requires proof inter alia that Congress either has criminalized all disclosures of

202 See generally Nimmer, supra note 155, at 333 \& n.106; Developments, supra note 187 , at 1242 .

203 Of course, the CIA did "show more," specifically that the disclosed information was CIA-related and actually classified. But proof of these factors would not seem to be any more dispositive than proof of classifiability in demonstrating the inevitable existence of a "clear and present danger." But cf. United States v. Boyce, 594 F.2d 1246, 1251 (9th Cir. 1979) (18 U.S.C. $\$ 798$ prohibits publication of classified communications systems data whether or not the information is properly classifiable; court engaged in no constitutional analysis).

204 New York Times v. United States, 403 U.S. 713, 714 (1971) (per curiam).

205 Exec. Order No. 12,356, §1.1(a)(3), 47 Fed. Reg. 14,874, 14,875 (emphasis added). added).

${ }^{206}$ New York Times, 403 U.S. at 726-27 (Brennan, J., concurring) (emphasis

207 Id. 730 (Stewart, J., concurring) (emphasis added).

208 The certainty of harm required by Justices Brennan and Stewart indicates that even proof that information warrants a "Top Secret" classification fails to satisfy the New York Times standard. 
correctly classified information or possesses constitutional authority to so act in the future. ${ }^{209}$ It has been shown in subsection III.B.1. above that neither predicate requirement exists. The private citizen can speak free of governmental restraint. ${ }^{\mathbf{2 1 0}}$

209 See supra text accompanying notes 146-49.

210 Some disclosures of defense-related, classifiable information, e.g., those made "willfully," are, of course, criminal. See supra text accompanying notes 185-87. A much more sympathetic case for injunctive relief would thus be presented if the government proved not only that impending speech was classified and classifiable, but criminal to boot. If Congress agreed, and provided statutory authorization for injunctive relief in these circumstances, of. 42 U.S.C. $\$ 2280$ (1976) (authorizing injunctive relief against criminal disclosures of "Restricted Data"), the stage would be set for an examination of the congressional power to authorize prior restraints. As argued in the text, Congress cannot lower the New York Times presumption in the private citizen context to the extent that injunctions issue upon mere proof that impending speech will disclose classified and classifiable data. The hypothetical law proposed here, though, suggests a middle ground, that injunctive relief be available upon proof that criminal disclosures of such data will occur, even if the speech at stake is not suppressible under New York Times. At first glance, the case in favor of the hypothetical enactment's constitutionality seems strong. If speech is criminal, it is by definition "unprotected." What harm, then, can flow from enjoining activity that lies outside the realm of first amendment protection? An order simply commanding the defendant to refrain from publishing a given work is not vague. The danger of chilling the defendant's exercise of protected first amendment rights is hence non-existent. See Kalven, The Supreme Court, 1970 Term, Foreword: Even When a Nation Is at War, 85 HARv. L. Rev. 3, 33 (1971); The Supreme Court, 1970 Term, 85 HARv. L. Rev. 3, $207-08$ (1971). Conversely, there is much to be said for such injunctions. By preventing the proposed speech, the judiciary shields the public from the serious harms that render the speech "unprotected" in the first place. "Prevention of disclosure in order to avoid serious damage . . . " writes former Director Colby, "better serves the national interest than punishment after disclosure." Colby Letter, supra note 56, at $68 \mathrm{a}$.

In theoretical terms, the argument in favor of constitutionality rests on the notion that there is no right to say everything once. Cf. Times Film Corp. v. City of Chicago, 365 U.S. 43, 48 (1961) (no right to exhibit every movie once); but see Kalven, supra, at 34. The problem with prior restraints is not that they prevent speech per se. But see Southeastern Promotions Ltd. v. Conrad, 420 U.S. 546,559 (1975). Rather, "[t]he special vice of a prior restraint is that communication will be suppressed . . . before an adequate determination that it is unprotected by the First Amendment." Pittsburgh Press Co. v. Pittsburgh Comm'n on Human Relations, 413 U.S. 376, 390 (1973); see generally Litwack, The Doctrine of Prior Restraint, 12 Harv. C.R.-C.L. L. REv. 519 (1977). An injunction that issues only after a court determination that the proposed speech is unprotected might thus be said not to threaten the harms addressed by prior restraint analysis.

But can the requisite "adequate determination" be made in the injunctive forum? Consider, for example, a case in which the government believes that an individual is willfully planning to publish defense-related information that he or she has reason to believe could be used to injure the United States. As discussed above, see supra text accompanying note 187, if the government's characterization of both motive and content is accurate, actual publication is criminal. Under the proposed law, the criminal act could be enjoined as well if identical showings were made before the fact. What is troubling about this notion is that the shift from a criminal to an anticipatory proceeding is not result-neutral. The probability that the government will succeed is much greater in the latter. For one thing, an attempt to secure civil injunctive relief does not.trigger a presumption of innocence or a requirement that the government prove its case beyond a reasonable doubt. 


\section{Enforced by an Injunction Directed Towards Future,} Unascertained Communications

Assume finally that a citizen has previously revealed in some fashion CIA-related information meeting the dual tests of classification and classifiability. The government now asks for an order forbidding similar behavior in the future. This request must fail because, as argued in subsection III.B.I. above, such behavior is not criminal, either currently or potentially; a fortiori, it cannot be enjoined.

See Cooper v. Mitchell Bros., 102 S. Ct. 172 (1981). Moreover, injunctive defendants are not guaranteed the assistance of counsel and cannot have their case tried to a jury. Compare Gorin v. United States, 312 U.S. 19, 31-37 (1941) (issue of "defense-relatedness" a jury issue in criminal proceedings under 18 U.S.C. $\S 794(\mathrm{a}))$.

One other factor favors the government. The very nature of this particular restraint calls for predictions of the reasonable consequen zes of disclosure. Given "the visage of overriding importance" that inheres in all security claims, Brown v. Glines, 444 U.S. 348,369 (1980) (Brennan, J., dissenting), it is quite likely that, in making the requisite prediction, courts will be inclined to afford the government the benefit of the doubt. E.g., United States v. Progressive, Inc., 467 F. Supp. 990 (W.D. Wis.), appeal dismissed mem., 610 F.2d 819 (7th Cir. 1979). See Developments, supra note 187, at 1241. When the calculation takes place in an after-the-fact criminal proceeding, however, borderline yet protected speech may be saved by the countervailing influence of hindsight. Id. No such check is present in the injunctive forum.

Furthermore, even if one assumes that the process of appellate review will ultimately void all erroneously granted injunctions, while a lower court's order remains in effect, the defendant has no choice but to obey. Disobedience is likely to constitute contempt even if the order is substantively invalid. See Walker v. City of Birmingham, 388 U.S. 307 (1967). But see Barnett, The Puzzle of Prior Restraint, 29 Stan. L. Rev. 539, 553-56 (1977). As a result, protected speech will be delayed at least until reversal on direct appeal can be procured. By then the desired political discussion may have lost much of its value. See Carroll v. President of Princess Anne, 393 U.S. 175, 182 (1968).

The advantages are all with the government in injunctive proceedings. It is thus reasonable to attempt to reset the balance by requiring more of the state when it seeks to enjoin rather than convict. Congress should not be able to ignore this imbalance at will and thereby deprive free speech of its needed breathing space. But see Progressive, discussed supra text accompanying notes 137-44.

Nothing in Kingsley Books, Inc. v. Brown, 354 U.S. 436 (1957) requires a contrary decision. In that case the Court upheld the constitutionality of a New York statute that authorized state court injunctions against the sale or distribution of books held to be obscene after trial. The law apparently required the state to make no greater showing of obscenity than was required in a criminal proceeding. Id. 440 , 442. In reaching its decision the Court relied heavily on the fact that the statute provided injunctive defendants with procedural safeguards on a par with those afforded criminal defendants. Id. 443. The Court assumed as well that under New York law disobedience of an unlawful order was not contemptuous. Id. 443 n.2. Furthermore, the Court was dealing with a restraint geared solely for determinations of obscenity. Because scrutiny of this sort requires few, if any, predictions as to harm, it is quite likely that obscenity can be judged as accurately prior to distribution as after. L. Tribe, AMERICAN Constiturional LAw 730 (1978). The special vices of the injunctive forum were thus not present in Kingsley Books. The decision cannot be viewed as authority for cases in which they are. 
Concluding otherwise, moreover, rejects the reasoning of Near v. Minnesota ex rel. Olson. ${ }^{211}$ As noted before, the Supreme Court in Near voided an injunction commanding the defendant to cease publishing "malicious, scandalous or defamatory" periodicals. ${ }^{212}$ But what was wrong with such an order? The four dissenters argued that in essence the Minnesota courts had simply ordered the defendant to comply with preexisting, operative legal duties. The statute authorizing the injunction merely provided a means of bringing direct pressure ${ }^{213}$ to bear on those who, like the defendant, had previously demonstrated a contempt for the societal bar on injurious publication. Injunctions conditioned on proof of previous statutory violation were merely, to the dissenters, "remed[ies] to be enforced by a suit in equity." 214 Furthermore,

the injunction did not prevent [the defendant] from continuing to publish at all; it only restrained him from publishing a "malicious, scandalous and defamatory" newspaper. Thus, the publisher would be guilty of contempt and punished only as and when he committed subsequent offenses. Theoretically, therefore, the statute could hardly be said to set up prior restraint. On paper, it was a system for subsequent punishment by contempt procedure.215

The Near majority, however, focused on the fact that neither the authorizing statute nor the injunction itself provided any concrete guidance as to what constituted "malicious, scandalous or defamatory" publication. ${ }^{216}$ Thus,

in practice, the system was bound to operate as a serious prior restraint. Punishment could be summarily dispensed by a single official, without jury trial or the other protections of criminal procedure, for infraction of a loose and illusive mandate. Under such circumstances, any publisher seeking to avoid prison would, in sheer selfprotection, have to clear in advance any doubtful matter with the official wielding such direct, immediate and un-

211283 U.S. 697 (1931).

212 Id. 702.

213 While a statutory proscription poses but "a mute, impersonal threat," an injunction that "affirmatively singl[es] out [a] would-be disseminator . . . is apt to cause more second thoughts." L. TruBe, supra note 210 , at 726 n.2.

214283 U.S. at 735 (Butler, J., dissenting); see also Times Film Corp. v. City of Chicago, 365 U.S. 43, 57 (1961) (Warren, C.J., dissenting).

215 Emerson, supra note 97, at 654 (footnote omitted).

216283 U.S. at 712 . 
impeded power to sentence. The judge would, in effect, become a censor. ${ }^{217}$

Near accordingly established that, at a minimum, valid judicial restraints cannot suffer from the ills of vagueness. ${ }^{218}$ Even judges, notwithstanding their relative institutional sympathy for first amendment values, ${ }^{219}$ cannot be trusted with the unbridled power to license, 220 " $[\mathrm{f}]$ or history prove[s] that judges too were sometimes tyrants." 221

Judged by this standard, an order forbidding future disclosures that are both classified and classifiable must fail. The latter term alone incorporates substantial vagueness, for determinations of classifiability require subtle judgments of both probability and gravity of potential harm.222 Enjoined individuals who continue to speak out about national security may, as a result, often find it necessary to obtain prior court approval. "This is of the essence of censorship." 223

\section{Conclusion}

The foregoing analysis demonstrates that the CIA cannot restrain private citizens to the extent it wishes to muzzle Snepp. ${ }^{224}$

217 Emerson, supra note 97, at 654.

218 Accord, Nebraska Press Ass'n v. Stuart, 427 U.S. 539, 568 (1976); Pittsburgh Press Co. v. Pittsburgh Comm'n on Human Relations, 413 U.S. 376, 396-97 (1973) (Burger, C.J., dissenting).

219 See Freedman v. Maryland, 380 U.S. 51, 57-58 (1965).

220 But cf. Smith v. Daily Mail Publishing Co., 443 U.S. 97, 101-04 (1979) (finding it unnecessary to determine whether a prior restraint inheres in a statute barring publication of a juvenile offender's name without prior written court approval).

221 Poulos v. New Hampshire, 345 U.S. 395, 426 (1953) (Douglas, J., dissenting).

222 See supra note 161 ; of. Paris Adult Theatre I v. Slaton, 413 U.S. 49, 73 (1973) (Brennan, J., dissenting) (concept of "obscenity" hopelessly vague).

223 Near, 283 U.S. at 713.

224 The fact that the CIA "lost" in the hypothetical cases against private citizens is hardly surprising. The sweeping nature of the postulated requests emanate from a philosophy completely foreign to American jurisprudence. One perhaps could therefore contend that the analysis has picked on "straw men." In response, I offer the following:

(1) It is true that "closer questions" could have been created. For example, what result if the CIA seeks an injunction ordering presubmission of all future CIA-related works written by a defendant who has previously revealed the names of several undercover agents? The simple response is that the CIA has deemed the latter complication irrelevant. The CIA has asserted that it is entitled to injunctive relief against current and former agents upon mere proof that a prior unilateral communication contained any information concerning the Agency. The hypotheticals 
But Snepp is not a "private citizen." $\mathrm{He}$ is an individual who (1) signed a secrecy contract, and (2) obtained access to classified materials through prior CIA employment. Parts IV and V analyze the relevance of these factual distinctions.

\section{The Relevance of the Contract}

Few today would assert that constitutional rights are inalienable. On the contrary, the concept of waiver is firmly established. ${ }^{225}$ Why isn't this perspective the key to unlocking Marchetti,220 $K n o p f,{ }^{227}$ and Snepp? ${ }^{228}$ Marchetti and Snepp, after all, voluntarily agreed to contractual provisions authorizing the CIA restraints. Thus what possible basis for first amendment objection can they have? Didn't they, upon signing their contracts, simply relinquish any first amendment rights they previously possessed as private citizens, at least as to CIA-related information that they would not have learned but for their employment? Doesn't the existence of the contract end their cases and moot first amendment analysis? 229

Though this argument may appear strong at first, it clearly proves too much. Even in the realm of private law, contracts are

have thus been designed to mirror the actual CIA requests in all respects except one-the identity of the speaker. "More complicated" fact patterns would simply have introduced extraneous issues.

(2) Apparently not all agree with the "straw man" label. The National Security Agency (NSA), for example, has stated that if voluntary compliance cannot be secured, it will seek legislation requiring prepublication review of all research papers dealing with cryptography. See N.Y. Times, Jan. 24, 1982, at 19, col. 1; L.A. Times, Feb. 1, 1981, at 1, col. 1. Cf. N.Y. Times, Mar. 30, 1982, at 9, col. I (quoting an Administration official's complaint about "a strong belief in the academic community that they have an inherent right to teach, conduct research and develop exchange programs free of Government review or oversight"); see also 18 U.S.C. $\$ 798$ (1976) (criminalizing the transmission of information concerning U.S. cryptographic methods or devices).

225 See, e.g., Johnson v. Zerbst, 304 U.S. 458 (1938).

226 United States v. Marchetti, 466 F.2d 1309 (4th Cir.), cert. denied, 409 U.S. 1063 (1972).

227 Alfred A. Knopf, Inc. v. Colby, 509 F.2d 1362 (4th Cir.), cert. denied, 421 U.S. 992 (1975).

228 Snepp v. United States, 444 U.S. 507 (1980) (per curiam).

229 Suggestions of such an analysis appear in United States v. Snepp, 595 F.2d 926, 932-34 (4th Cir. 1979), rev'd in part, 444 U.S. 507 (1980) (per curiam); Note, United States v. Marchetti and Alfred A. Knopf v. Colby: Secrecy 2; First Amendment 0, 3 Hastings Const. L.Q. 1073, 1076 (1976) (quoting unreported district court opinion in Marchetti).

Apparently this logic appealed to former President Carter as well:

I don't look on Frank Snepp as one of the greatest whistle-blowers of all times. He signed voluntarily a contract, later confirmed this agreement with the C.I.A. that before his book was published that [sic] it would be examined to assure there were no revelations of secret material. . . .

[T] The Attorney General has decided that when a contract is signed that [sic] it ought to be honored.

N.Y. Times, Mar. 3, 1978, at Al0, col. 4. 
not enforced simply because they are made. Usurious and unconscionable bargains are but two that courts refuse to acknowledge even when they truly reflect the parties' intent. Contracts are enforced only if the promises they embody are substantively compatible with the goals of public policy, however defined. Enforcement thus presupposes substantive inquiry.

To reject this premise one must be willing to accept and to enforce any contract, no matter what its terms. One must believe that it would be proper for the CIA to extract any promise at all from its agents in return for giving them their jobs. Of course, even in such a world the CIA would not possess complete carte blanche. It could impose only those conditions that its bargaining power justified and that current political mores tolerated. The crucial point, however, is that neither the Constitution nor any other legal doctrine would play any role in this checking process. The distribution of benefits would be deemed the dispersal of "privileges," a process over which the state possessed plenary legal power. Even if the CIA conditioned employment on an applicant's promise to vote Republican or to speak only on Tuesdays, constitutional arguments would simply remain irrelevant. The Supreme Court long ago explicitly and correctly rejected such a view. ${ }^{230}$

This is not to say that the specific restrictions imposed on Snepp are necessarily unconstitutional. Perhaps they are reasonable in light of the consideration received-but perhaps not. I leave for part $\mathrm{V}$ the resolution of this point. For present purposes, it is sufficient to note that an inquiry into the substantive validity of the restraints must be undertaken. The mere fact of the contract's existence is the beginning, not the end, of the analysis: "[T]he First Amendment limits the extent to which the United States, contractually or otherwise, may impose secrecy requirements upon its employees and enforce them with a system of prior censorship." 231

230 For at least a quarter-century, this Court has made clear that even though a person has no "right" to a valuable governmental benefit and even though the government may deny him the benefit for any number of reasons, there are some reasons upon which the government may not rely. It may not deny a benefit to a person on a basis that infringes his constitutionally protected interests-especially, his interest in freedom of speech.

Perry v. Sindermann, 408 U.S. 593, 597 (1972). Compare McAuliffe v. Mayor of New Bedford, 155 Mass. 216, 220; 29 N.E. 517, 517-18 (1892) (Holmes, J.) ("The petitioner may have a constitutional right to talk politics, but he has no constitutional right to be a policeman .... The servant cannot complain, as he takes the employment on the terms which are offered him.").

231 Marchetti, 466 F.2d at 1313 (emphasis added). 
Perhaps this point can be made clearer by considering the same restrictions imposed without a contract. Suppose Congress had attempted to restrain Snepp by passing a law that provided for the same restrictions found in Snepp's secrecy agreement. All agents would then have assumed their jobs with presumed knowledge of the attendant restrictions. Logically one could argue that by taking their jobs with this knowledge, the agents had consented to the restrictions and had hence waived any objection thereto. Yet the very absurdity of this proposition is perhaps best evidenced by the fact that neither litigants nor judges have seen fit to raise it in suits challenging the constitutionality of statutorily imposed First Amendment restrictions. For example, when the federal Hatch Act ${ }^{232}$ came under attack in United States Civil Service Commission $v$. National Association of Letter Carriers ${ }^{233}$ and when New York's Feinberg Law ${ }^{234}$ was challenged in Keyishian v. Board of Regents, ${ }^{235}$ the analysis focused immediately on the substantive issue, the power of the state to impose the restraints in question. Implicit in these decisions is a determination that one's "waiver" cannot cure an invalid statute; a statute stands or falls on its merits. The same rule should govern contracts.

The reasoning in Elrod v. Burns ${ }^{236}$ reinforces this conclusion. There several plaintiffs challenged the patronage system in Cook County, Illinois, alleging that the first amendment rendered void any dismissal of a public official motivated solely by the official's refusal to affiliate with the political party then in power. In dissent, Justice Powell argued that these employees had no grounds for complaint. They had "apparently accepted patronage jobs knowingly and willingly, while fully familiar with the 'tenure' practices long prevailing in the Sheriff's Office." ${ }^{237}$ Speaking for a three-man plurality, Justice Brennan quickly refuted the waiver argument:

Petitioners contend that even though the government may not provide that public employees may retain their jobs only if they become affiliated with or provide support for the in-party, respondents here have waived any objection

2325 U.S.C. $\$ 7324$ (1976) (barring federal employees from taking an active part in political campaigns).

233413 U.S. 548 (1973).

234 N.Y. Education Law $\$ 3022$ (McKinney 1981) (providing for dismissal of state school employees who utter seditious words).

235385 U.S. 589 (1967).

236427 U.S. 347 (1976) (plurality opinion).

237 Id. 380 (Powell, J., dissenting). 
to such requirements. The difficulty with this argument is that it completely swallows the rule. Since the qualification may not be constitutionally imposed absent an appropriate justification, to accept the waiver argument is to say that the government may do what it may not do. ${ }^{238}$

A "waiver" thus cannot cure an invalid "practice." And, to repeat, the same rule must govern contracts, for the scope of substantive rights should not depend upon the government's choice of lawmaking process. That Snepp signed a contract is relevant only to the extent that the document evidences, as would a statute, the state's desire to impose the restrictions at issue. ${ }^{239}$ His signature does not insulate these restraints from first amendment scrutiny.

\section{The Relevance of Former GiA Employment}

In the public employment field as in others, the first amendment has proved to be less than absolute. Over the years, the Supreme Court has rejected several challenges in which workers have contested the right of governmental employers to condition employment on the surrender of first amendment rights. It is constitutional, for example, for government employers to require that all employees take loyalty oaths of a prescribed variety. ${ }^{240}$ Civil service employment, the Court has further ruled, can be tied to a pledge that the employee refrain from various partisan political activities. ${ }^{241}$ Limited "agency shop" conditions also pass muster: state employers can insist that all workers help underwrite the collective bargaining efforts of their union representative, notwithstanding a given worker's ideological opposition to all forms of public sector unionism. ${ }^{242}$

$238 \mathrm{Id} .360 \mathrm{n} .13$ (plurality opinion). This aspect of Elrod was specifically reaffirmed by a majority of the Court in Branti v. Finkel, 445 U.S. 507, 512 n.6 (1980).

239 The CIA might agree that a substantive inquiry must be made, yet assert that the existence of a signed secrecy agreement should count for something. In doctrinal terms, it might be argued that in judging the validity of a secrecy contract, courts must accord some weight to the fact that the agent-signer at one time believed its terms to be acceptable. This contention is unpersuasive. Before signing on with the CIA, each agent, to the extent that he or she pondered the issue at all, probably wondered, "Can I live with these restrictions?" "Yet the proper question for constitutional purposes is "Should an agent have to live with these restraints?" The signature of an agent thus has little probative value.

240 Cole v. Richardson, 405 U.S. 676 (1972).

241 United States Civil Service Comm'n v. National Ass'n of Letter Carriers, 413 U.S. 548 (1973).

242 Abood v. Detroit Bd. of Educ., 431 U.S. 209 (1977). 
On the other hand, numerous employee challenges have succeeded. Thus, employment of a college professor cannot be conditioned on a pledge that the professor refrain from protected associational activities. ${ }^{243}$ Nor, as a first approximation, can appointive, non-civil service employment be conditioned on a promise that the employee switch party affiliation whenever an out-party is voted into office.244 And even those employees who work within an "agency shop" setting retain some protection, for they cannot be compelled to support union activities that are both unrelated to collective bargaining and abhorrent to the worker. ${ }^{245}$ The Supreme Court has thus determined that the first amendment tolerates some, but not all, arrangements whereby the state exchanges employment for the renunciation of expressive rights.

In only one pre-Snepp ${ }^{246}$ case, however, had the Court ever indicated that public employment could be accompanied by systems of prior review. In Brown v. Glines, ${ }^{247}$ the Court sustained Air Force regulations under which no serviceman could, without the prior approval of a base commander, either circulate or distribute various materials while still on base. ${ }^{248}$ These milder restraints differ markedly, however, from those sought in Snepp. Because the requirement of base commander approval burdened only onbase activities, it could be evaded in two ways. Servicemen could leave base, or, more drastically, they could resign from the Air Force. By contrast, even resignation from the CIA cannot free a former agent from his duty to submit to prior CIA review of all CIA-related speech. The covenants contained in a CIA secrecy agreement accompany its signer in perpetuity, no matter where he or she goes or how long he or she lives. ${ }^{249}$ In no case, therefore, had the Court ever previously sustained restraints of the magnitude at issue in Snepp. It was highly inappropriate for the Court to have dismissed Snepp's appeal summarily and with little more than bare citations to inapposite precedent such as Glines.

243 Keyishian v. Board of Regents, 385 U.S. 589 (1967).

244 Branti v. Finkel, 445 U.S. 507 (1980); Elrod v. Burns, 427 U.S. 347 (1976) (plurality opinion).

245 Abood, 431 U.S. at 234-35.

246 Snepp v. United States, 444 U.S. 507 (1980) (per curiam).

247444 U.S. 348 (1980).

248 Analogous Navy and Marine regulations were sustained in a companion case, Secretary of Navy v. Huff, 444 U.S. 453 (1980) (per curiam).

249 Thus, Glines would be better precedent if the CIA were to impose prepublication review duties solely on current, not former, agents. And the fact patterns would converge even further if the sanctions for disobedience were merely, as in Glines, demotion and dismissal. See also Pickering v. Board of Educ., 391 U.S. 563, 572 n.4 (1968). 
The proper approach must begin with more basic first amendment analysis. The first step is a determination of the appropriate standard of review. On this score, no clear governing law exists, but several potential guideposts are discernible. One is surely Pickering $v$. Board of Education, ${ }^{250}$ a case in which the Supreme Court held it to be unconstitutional for a school board to fire a teacher in retaliation for prior statements critical of the board's performance. Justice Marshall, in reaching this result, wrote:

"[T]he theory that public employment which may be denied altogether may be subjected to any conditions, regardless of how unreasonable, has been uniformly rejected." . . . At the same time it cannot be gainsaid that the State has interests as an employer in regulating the speech of its employees that differ significantly from those it possesses in connection with regulation of the speech of the citizenry in general. The problem in any case is to arrive at a balance between the interests of the teacher, as a citizen, in commenting upon matters of public concern and the interest of the State, as an employer, in promoting the efficiency of the public services it performs through its employees. ${ }^{251}$

Implicit in Pickering seems to be a determination that "reasonableness" is the standard by which to judge the conditioning of public sector employment on a relinquishment of some measure of first amendment rights. If the employer can show that the restrictions reasonably help effectuate the employer's specific mission, the agreement is enforceable.

Whether or not this interpretation of Pickering is correct, ${ }^{252}$ the decision simply cannot be mechanically transposed into the secrecy agreement context. Pickering dealt only with the state's power to restrict the speech of its current employees. ${ }^{253}$ The Court was concerned there only with the question of when employee speech could "furnish grounds for dismissal." 254 Thus, nothing said there directly indicates how one judges a restraint that lasts not

250391 U.S. 563 (1968).

251 Id. 568 (quoting Keyishian, 385 U.S. at 605-06) (emphasis added) (citations omitted).

252 See generally Comment, supra note 89 , at 676-82.

253 This article does not purport to decide whether all of the CIA's restraints would be constitutional if imposed solely upon currently employed agents. See generally infra text accompanying note 334; see also supra note 249 and infra note 310 .

254 Pickering, 391 U.S. at 569. 
simply for the duration of employment, but for the duration of an employee's life. Moreover, later cases, with little discussion of Pickering, espouse a stricter rule even in the dismissal context. In Elrod v. Burns, ${ }^{255}$ Justice Brennan argued that any

significant impairment of First Amendment rights must survive exacting scrutiny. ... In short, if conditioning the retention of public employment on the employee's [surrender of first amendment rights] is to survive constitutional challenge, it must further some vital governmental end by a means that is least restrictive of freedom of belief and association in achieving that end, and the benefit gained must outweigh the loss of constitutionally protected rights. ${ }^{256}$

While it is true that Justice Brennan's plurality opinion attracted only two other votes, ${ }^{257}$ it is clear that the quoted sentiments commanded the support of a majority of the Court, for the three dissenters acknowledged as well that "strict scrutiny" was proper. ${ }^{258}$ Moreover, explicit endorsement was provided by a Court majority in Branti $v$. Finkel: ${ }^{259}$ "[U]nless the government can demonstrate 'an overriding interest' 'of vital importance' requiring that a person's private beliefs conform to those of the hiring authority, his beliefs cannot be the sole basis for depriving him of continued public employment." 280 Elrod and Branti hence suggest that even when a governmental employer relies solely on the dismissal sanction, any attempt to enforce a condition on employment first triggers a requirement that the state make extraordinary showings in order to justify the underlying agreement. ${ }^{261}$

255427 U.S. 347 (1976) (plurality opinion).

250 Id. 362-63 (citations and footnote omitted).

257 Significantly, Justice Marshall, the author of Pickering, did join Justice Brennan.

258427 U.S. at 381 (Powell, J., dissenting, joined by Chief Justice Burger and Justice Rehnquist); accord, Abood, 431 U.S. at 259 (Powell, J., concurring in judgment).

250445 U.S. 507 (1980).

200 Id. 515-16 (quoting Elrod, 427 U.S. at 362, 368) (citations omitted) (emphasis added).

261 It has been argued that Elrod applies when a restraint threatens freedom of belief or association, but that Pickering governs when only freedom of speech is implicated. Van Ooteghem v. Gray, 628 F.2d 488, 497-500 (5th Cir. 1980) (Reavely, J., specially concurring). The panel majority in Van Ooteghem rejected this dichotomy and held that Elrod and Branti had "refined" Pickering's approach completely. Id. 493 n.4. Rehearing en banc was scheduled in order to resolve this question, but the panel was ultimately affirmed with no resolution of the disputed issue. The court found that the plaintiff would prevail no matter what standard applied. Van Ooteghem v. Gray, 654 F.2d 304 (5th Cir. 1981) (en banc) (per curiam). 
In Snepp, the Court itself betrayed considerable uncertainty as to how to proceed. Initially the law was stated as follows: "[T]he GIA [is entitled] to protect substantial government interests by imposing reasonable restrictions on employee activities that in other contexts might be protected by the First Amendment." 262 This sounds like Pickering. But in the very next sentence the Court spoke of "compelling interest[s]," ${ }^{203}$ thus invoking a term usually reserved for "strict scrutiny" review. Finally, the Court ended its footnote, magnified the confusion, and completed the circle with a second reference to reasonableness. ${ }^{264}$

Whatever the label, no court should enforce a CIA secrecy agreement unless first satisfied that the embodied restraints survive review akin to that demanded in Elrod and Branti. ${ }^{265}$ To the extent that the Court in Snepp indicated otherwise, it erred, for the restrictions at stake tread heavily on first amendment values. Consider first the requirement of prepublication review. On its face, this appears to be the milder of the two main restrictions, for all the CIA obtains thereby is a thirty-day opportunity to prescreen a manuscript; no ultimate powers of censorship expressly flow from the covenant. But in reality the restraint is very serious. ${ }^{268}$ Even

262 Snepp, 444 U.S. at 509 n.3 (citations omitted).

263 Id.

264 "The agreement that Snepp signed is a reasonable means for protecting this vital interest." Id.

265 See infra note 299 for a discussion of the distinction between the proposed standard and the Elrod/Branti standard.

266 Initially it should be noted that the proposed restraint fails to comply with the procedural requirements set forth in Freedman v. Maryland, 380 U.S. 51 (1965). There the Court held that a "process which requires the prior submission of a film to a censor avoids constitutional infirmity only if it takes place under procedural safeguards designed to obviate the dangers of a censorship system." Id. 58. Three specific procedural incidents were deemed essential: "( 1 ) the censor must have the burden of instituting judicial proceedings; (2) any restraint prior to judicial review can be imposed only briefly in order to preserve the status quo; and (3) a prompt judicial determination of obscenity must be assured." Id. $61 \mathrm{n}$. (Douglas, $J$., concurring); see also id. 58-59 (majority opinion); see generally L. Trune, supra note 210 , at 714-16. Subsequent cases make clear that these requirements apply to prior restraints in general and are not peculiar to the film regulation context. See, e.g., Blount v. Rizzi, 400 U.S. 410 (1971). Only "time, place and manner" restraints of the type sustained in Cox v. New Hampshire, 312 U.S. 569 (1941), apparently need not satisfy the Freedman criteria. See Southeastern Promotions, Ltd. v. Conrad, 420 U.S. 546, 555 (1975); cf. State v. Harvey, 108 N.H. 139, 229 A.2d 176 (1967) (rejecting a post-Freedman attack on the statute in issue in Cox). Since the proposed CIA restraint is clearly not of this sort, see supra text accompanying notes 104-07, it must be tested against the standards listed above.

The first poses no problem since Snepp established that the CIA bears the burden of seeking injunctive relief. See supra text accompanying notes 66-67. However, the CIA's entitlement to a thirty-day freeze on the status quo is highly debatable. In United States v. Thirty-Seven Photographs, 402 U.S. 363 (1971), the Court faced an attack on a statute authorizing customs agents to seize material 
a "mere" thirty-day delay can obliterate the value of political discourse; what is timely today may be irrelevant or inconsequential within a month. ${ }^{207}$

More fundamentally, it is simply not true that no ultimate censorship will result. Consider an individual who, like Snepp, wishes to publish statements critical of the CIA. Is such behavior as likely to occur when the author knows that he must first face and confront his antagonist? Whether out of shyness or out of a desire to avoid confrontation and aggravation, it stands to reason that prepublication review substantially deters negative commentary about the censor. ${ }^{288}$ Tolstoy, for one, experienced these feelings:

You would not believe how, from the very commencement of my activity, that horrible Censor question has tormented mel I wanted to write what I felt; but all the same time it occurred to me that what I wrote would not be permitted, and involuntarily I had to abandon the work. I abandoned, and went on abandoning, and meanwhile the years passed away.260

As Professor Cox writes, "[t]he pressure to trim in order to satisfy the censor is ever present." 270 Prepublication review by its nature hence induces self-censorship and "self-censorship, compelled by the State, would be a censorship affecting the whole public, hardly less virulent for being privately administered." 271

Doses of courage are not the complete answer. The dangers of ultimate, nonjudicial censorship remain formidable even if the

believed to be obscene. The statute's constitutionality was saved only after the Court first construed the law to require the commencement of judicial confiscation proceedings within fourteen days of seizure. Id. 373-74. It would be perverse if CIA censors could impound "political speech," "speech in which the element of timeliness may be important," Carroll v. President of Princess Anne, 393 U.S. 175, 182 (1968), for over twice as long. Cf. Comment, supra note 89, at $704 \mathrm{n} .274$ (CIA entitled to no more than 10 days to review submissions). Moreover, no assurance is provided that disputes over what is "classified" and "classifiable" will be resolved expeditiously. In Knopf, for example, the Fourth Circuit rendered no decision for over eight months following argument. Cf. Thitty-Seven Photographs, 402 U.S. at 373-74 (allowing only two months for district courts to render decision following the initiation of a confiscation action).

Procedural defects such as these can of course be rectified. By contrast, the dangers of prior review noted in the text would exist even if such corrective measures were taken, though perhaps somewhat less forcefully.

207 See Carroll, 393 U.S. at 182; Emerson, supra note 97, at 657.

208 See Note, Enforceability of CIA Secrecy Agreements: A Constitutional Analysis, 15 Colvm. J.I. \& Soc. Pross. 455, 502 (1980).

209 Quoted in Times Film Corp. v. City of Chicago, 365 U.S. 43, 66 n.6 (1961)

(Warren, C.J., dissenting).

270 Cox, supra note 2 , at 9 .

271 Smith v. California, 361 U.S. 147, 154 (1959). 
author conquers the tendency towards self-censorship and writes without fear. In theory; a manuscript containing information that is embarrassing to the CIA but is neither classified nor classifiable should be approved without difficulty. CIA censors should quickly recognize that the manuscript does not breach security and release it for publication. But is this a realistic portrayal of what will occur? Common sense suggests not. It seems more likely that " $[t]$ he temptation for officials . . . to oppose disclosure of embarrassing or politically damaging information is ... irresistible." 272 As CIA officials are no exception, ${ }^{273}$ it is highly improbable that CIA censors will be disinterested in the outcomes of their classifiability judgments. The censor's desire to protect his own group from an outsider's ${ }^{274}$ attack cannot help but inject a bias in favor of classifying information. Moreover, those who are selected by the CIA as censors undoubtedly hold strong beliefs in the mission of the CIA and its importance to national security.275 Because of such "ideological loyalty," CIA censors may almost instinctively translate an attack on the Agency into an attack on national security. If one believes that "what is good for the CIA is good for America," con-

272 The Supreme Court, 1970 Term, supra note 210 , at 202 (footnote omitted).

273 Indeed, in one post-Snepp decision, Judge Gesell, in passing on a motion for summary judgment, refused to grant the CIA constructive trust relief on the explicit ground that the record indicated that the CIA may have been abusing its rights under its secrecy agreements: "Agee . . . has presented evidence indicating that the CIA's past enforcement record bears a considerable correlation with the agency's perception of the extent to which the material is favorable to the agency." Agee v. Central Intelligence Agency, 500 F. Supp. 506, 509 (D.D.C. 1980); accord, Comment, supra note 89, at 697 ("The CIA has conceded in congressional hearings that it has selectively enforced the prior approval requirement against authors of books that are critical of the Agency.") (footnote omitted). See generally Snepp, The CIA's Double Standard, Newsweek, Jan. 25, 1982, at 10. But cf. Haig v. Agee, 453 U.S. 280, $309 \mathrm{n.61}$ (1981) (finding no merit to a claim that the government has been using its power to revoke passports on national security grounds "as a subterfuge to punish criticism").

Just recently the CIA agreed to settle a case with former director Colby out of court for $\$ 10,000$. Colby had "inadvertently published [his memoirs] without the changes and deletions insisted upon by the agency." Newsweek, Jan. 11, 1982, at 69 . The penalty suffered by Colby contrasts quite favorably with that imposed on Snepp, though it was Snepp who, under the facts as stipulated, published nothing that the agency could have validly excised.

274 The speaker here is, by hypothesis, a current or former member of the CIA "group." However, those who write negatively about the Agency are quickly relegated, in the minds of remaining CIA workers, to the status of an "outsider." See Chicago Tribune, Mar. 26, 1981, \$2, at 1, col. 2.

275 They must, of course, be trusted enough to merit a security clearance. More generally, a censor "is often acutely responsive to interests which demand suppression-interests which he himself represents-and not so well attuned to the more scattered and less aggressive forces which support free expression." Emerson, supra note 97, at 659; accord, Times Film Corp. v. City of Chicago, 365 U.S. 43, 65-66 (1961) (Warren, C.J., dissenting). 
sistency compels a belief that much anti-CIA literature should be suppressed. ${ }^{278}$ Of course, on occasion, apparent censor overzealousness may in reality be quite legitimate. Only censors may know or comprehend the significance of background information that renders a given piece of information dangerous. ${ }^{277}$ Nonetheless the danger of overzealousness induced by "tunnel-vision" cannot be denied. ${ }^{278}$ Nor can one ignore the professional incentives at work in classifiability determinations: "The function of the censor is to censor. He has a professional interest in finding things to suppress. His career depends upon the record he makes." 279 Their "records" in turn dependent upon an ability to find classifiable revelations, CIA censors, one would expect, most probably resolve all doubts in favor of suppression.

The second branch of the test for suppression, actual classification of the information, will provide no objective counterbalance to the censor's biases, simply because the test will almost always be passed. As numerous commentators have noted, overclassification has been and remains rampant:

Estimates as to the percentage of classified documents that are improperly included within the scope of executive classification ranged from Arthur Goldberg's 75 percent, with another 15 percent that need only short-term classifcation, to retired Department of Defense classification policy expert William G. Florence's 99.5 percent. $^{280}$

Thus, a grave danger exists that a significant number of manuscripts will contain information that has been classified in the past and that a censor erroneously believes to merit continuing classification. But, one might ask, won't an error in the determination of classifiability ultimately defeat any CIA attempt to enjoin pub-

276 Cf. Glines, 444 U.S. at 370 (Brennan, J., dissenting) (military officials' natural self-interest "inevitably influences their exercise of the power to control expression"); Developments, supra note 187, at 1135 ("Almost every government throughout history has viewed freedom of expression as a threat to national security.").

277 See United States v. Marchetti, 466 F.2d 1309, 1318 (4th Cir.), cert. denied, 409 U.S. 1063 (1972).

$278 \mathrm{Cf}$. Monaghan, supra note 100, at 523 ("those constantly exposed to the perverse and the abberational [sic] in literature are quick to find obscenity in all they see.").

279 Emerson, supra note 97, at 659; accord, Freedman v. Maryland, 380 U.S. $51,57-58(1965)$.

280 Comment, Government Information Leaks and the First Amendment, 64 CAxTF. L. Rev. 108, 118 n.34 (1976) (citation omitted); accord, Developments, supra note 187, at 1134, 1199-1202, 1215-16; Note, supra note 268, at 496. 
lication? And if so, hasn't the only constitutional route to suppression ${ }^{281}$ been foreclosed? Were litigation costless, instantaneous, and risk-free, one would have to agree that no danger of ultimate suppression inheres in the scenario sketched above. The author could publish at the expiration of the thirty-day period with confidence that any CIA attempt to stop him would be dismissed quickly and inexpensively. But of course real-world litigation does not conform to this description. As a result, avoidance of litigation is a valued end in itself, and this factor allows for bargaining. The GIA can obtain what it wants-specified manuscript deletionssimply by promising to accept the remainder and forego bringing suit. "[A] requirement of prior review," writes Ronald Dworkin, "makes what an author may say a matter of compromise, negotiation, and delay, all under the shadow of the threat of litigation, rather than a matter of what the author wants to say, which the First Amendment insists it should be." 282 In Bantam Books, Inc. v. Sullivan, ${ }^{283}$ the Supreme Court recognized and condemned the use of "informal sanctions-the threat of invoking legal sanctions and other means of coercion, persuasion, and intimidation" 284 as a method of suppressing protected, albeit objectionable, speech. An arrangement such as prepublication review, which facilitates identical forms of informal suppression, must accordingly be deemed constitutionally suspect.

Emphasis must be placed on the word "facilitate." Prepublication review renders "bargaining table" censorship a more likely occurrence, not a virtual certainty. Some authors will undoubtedly buck the pressures and take their cases to court. If they prevail, no ultimate censorship results. But what will have happened in the process to the "mere" thirty-day restraint? Even if the litigation proceeds at the "feverish" 285 pace exemplified by the Pentagon Papers case, complete judicial review will require extending the freeze on publication by roughly fifty percent. And this, of course, is the best-case scenario. More pessimistic predictions find support in the actual experience of the Knopf case.286 Whatever the magni-

281 See Freedman, 380 U.S. at 58-59.

282 Dworkin, supra note 143 , at 55 (footnote omitted) (emphasis in original). 283372 U.S. 58 ( 1963 ).

284 Id. 67.

285 New York Times Co. v. United States, 403 U.S. 713, 753 (1971) (Harlan, J., dissenting).

286 Alfred A. Knopf, Inc. v. Colby, 509 F.2d 1362 (4th Cir.), cert. denied, 421 U.S. 992 (1975). See also United States v. Thirty-Seven Photographs, 402 U.S. 363 (1971), discussed supra note 266. 
tude, the resulting "delays in adjudication may well result in irreparable damage both to the litigants and to the public." 287

The bottom line is simply that the proposed. CIA restraint places an entire aspect of each agent's political speech under the watchful eye of the very entity that is the subject of debate. At the very least, such a regime confers upon the agency an ability to control the timing and tenor of this debate for thirty days. But this is not all. One simply cannot ignore the inherently grave dangers of both greater temporal restriction and de facto absolute suppression. Nor should one forget that the speech thereby burdened-speech "relating to the CIA"-lies within the protection of the first amendment's "central" guarantee that "debate on public issues . . . be uninhibited, robust, and wide-open." 288 This premise is rejected in a world where prepublication review is enforced, to the detriment of all citizens. Secrecy agreement signers suffer, of course, because they lose forever the opportunity to participate fully in one arena of political discourse. They are relegated to a position of perpetual political inferiority as compared to their fellow citizens. ${ }^{289}$ They experience, moreover, fewer of the benefits of personal development that the right of unfettered speech is claimed to foster. ${ }^{290}$

The public also suffers gravely from such a serious restraint on core first amendment activity. Information concerning public issues is the lifeblood of democracy; an uninformed citizenry is, by definition, an ineffective check on both official misconduct and misguided policy. ${ }^{201}$ Partly in recognition of these truths, the Supreme Court has held that the first amendment embodies an independent

287 Times Film Corp. v. City of Chicago, 365 U.S. 43, 73 (1961) (Warren, C.J., dissenting).

288 New York Times Co. v. Sullivan, 376 U.S. 254, 270 (1964) (emphasis added); accord, First Nat'l Bank of Boston v. Bellotti, 435 U.S. 765, 776-77 (1978); Pickering v. Board of Educ., 391 U.S. 563, 573 (1968); Mills v. Alabama, 384 U.S. 214, 218 (1966); Thomhill v. Alabama, 310 U.S. 88, 101-02 (1940).

The further "protected" speech strays from this central core, the greater the allowable amount of governmental regulation. See Young v. American Mini Theatres, Inc., 427 U.S. 50 (1976) (pornography); Virginia State Bd. of Pharmacy v. Virginia Citizens Consumer Council, 425 U.S. 748, 771-72 n.24 (1976) (commercial speech).

289 See Dworkin, supra note 143 , at 56.

290 L. TruBe, supra note $210, \$ 12-1$, at 576-79.

291 See, e.g., New York Times, 403 U.S. at 728 (Stewart, J., concurring); Halperin \& Hoffman, Secrecy And The Right To Know, 40 LAw \& ConTEMP. Probs. No. 3, at 132, 134 (1976). For general discussions of the structural importance of free speech, see Richmond Newspapers, Inc. v. Virginia, 448 U.S. 555 , 586-88 (1980) (Brennan, J., concurring in judgment); The Supreme Court, 1979 Term, 94 HARv. L. REv. 1, 154-59 (1980), and sources cited therein. 
"right to know," under which a communication can itself merit protection even when the speaker may not. ${ }^{292}$ The teaching of these cases is thus that whether or not a speaker is "odious,"-for example, a contract breaker-one must always bear in mind the importance of what is said. Even if we believe that the speaker's actions warrant opprobrium, we must not act solely on this basis. In the process, we may silence an individual with valuable information to share, and thus end up hurting ourselves even more. The latter danger would appear to be especially grave when the silenced speaker is, like Snepp, a former insider with special expertise relative to the subject of his speech. ${ }^{293}$ "The opinions of government employees with expertise," notes one commentator, "are especially valuable to the public, particularly the opinions of dissenters." 294 The first amendment thus protects more than self-expression per se. It renders suspect as well all governmental actions which have the effect of "limiting the stock of information from which members of the public may draw." ${ }^{295}$ Prepublication review threatens exactly this sort of limitation.

Yet it would be error to conclude that the foregoing analysis of prepublication review irrebuttably demonstrates that the restraint is unconstitutional. No such conclusion can be drawn before one weighs in the balance the benefits of the restriction, or, more precisely, the harms that would result from its absence. Detailed analysis of the harm threatened by prepublication restraints does, however, serve a subordinate purpose. For once one knows the degree of the potential danger in question, one can gauge how great a showing of offsetting benefit the state must make in order to save its restriction. As the Court has held in another context, "the severity of the impairment measures the height of the hurdle the [restraint] must clear." 296 We have seen that the dangers of "mere" prepublication review are extremely serious. A fortiori, an express and absolute prohibition of an entire class of speech must threaten analogous dangers to both the speaker and the public. The CIA's

292 See, e.g., First Nat'l Bank of Boston v. Bellotti, 435 U.S. 765, 783 (1978); Stanley v. Georgia, 394 U.S. 557, 564-66 (1969).

293 Comment, supra note 89, at 702-03; accord, Pickering v. Board of Educ., 391 U.S. 563, 572 (1968) (because of the intimate knowledge of school operations possessed by teachers, "it is essential that they be able to speak out freely on such questions [of school policy]").

294 Comment, supra note 280, at 113; accord, Comment, supra note 89 , at 694 . 295 Bellotti, 435 U.S. at 783.

296 Allied Structural Steel Co. v. Spannaus, 438 U.S. 234, 245 (1978). 
ban on revealing classified and classifiable information is thus highly suspect as well. ${ }^{207}$

At bottom, what is perhaps most crucial is that both restraints last indefinitely. They are not mere temporal measures. They recognize no limitations as to time, place, or manner. Once an agent signs a secrecy contract, he or she is forever bound by the restraints it imposes. Even if the agent quits after only one day, any future attempt to speak out about the CIA-be it twenty, thirty, or fifty years later-cannot take place. At the earliest, the attempted communication will be released to the public after a thirty-day delay. If we must truly accept such drastic restrictions on our most precious right of free speech, it should be only after a demonstration that they are needed compromises that modern society demands. Any "significant impairment of First Amendment rights," Justice Brennan has written, "must survive exacting scrutiny." 298

297 It might seem plausible to argue that this restraint is actually less dangerous than prepublication review because, even if the prohibition limits the speaker's right of self-expression, no harm befalls the public's right to know. The theory would be that because classified and classifiable information is exempt from the disclosure requirements of the Freedom of Information Act, see 5 U.S.C. $\$ 552$ (b)(I) (1976), it simply makes no sense to say that the public as a whole has a right to know such data. See Dworkin, supra note 143, at 52. Thus, the argument goes, the public suffers no injury when a legal rule bars disclosure by a third party. The reasoning fails. Just because members of the public cannot compel the government to reveal certain data, it does not follow that they have no right to listen to another's voluntary revelation of the same information. Outlawing the latter act therefore does cause injury.

This conclusion should not be surprising. We have already determined that when the speaker is a private citizen, communications that are merely classified and classifiable cannot be suppressed. See supra text accompanying notes 154-203. Significantly, this conclusion derived in part from a recognition that this speech can be of great value to the public. See supra note 200 . Placing a former agent in the citizen's shoes does not diminish this value: "The inherent worth of the speech in terms of its capacity for informing the public does not depend upon the identity of its source . . ." First Nat'l Bank of Boston v. Bellotti, 435 U.S. 765, 777 (1978). Of course, "the source of the speech nevertheless may be relevant in determining whether a given message is protected under the First Amendment." Central Hudson Gas \& Elec. Corp. v. Public Serv. Comm'n, 447 U.S. 557, 585 (1980) (Rehnquist, J., dissenting) (footnote omitted). Different countervailing factors come into play with different speakers. Still, the analysis of countervailing factors must, as before, recognize that the information at stake may be of substantial value to the public.

This is not to say that the public's "right to know" embraces the entire arena of classified and classifiable information. Revelations of technical weapons systems data, for example, probably should not be entitled to the protection afforded by the doctrine. See United States v. Progressive, Inc., 467 F. Supp. 990, 994 (W.D. Wis.), appeal dismissed mem., 610 F.2d 819 (7th Cir. 1979); see generally Halperin \& Hoffman, supra note 291, at 141-43. The point is simply that a ban drawn along the lines of classification and classifiability is extremely imprecise. It keeps from the public information it presumptively has a right to hear from a willing speaker. See Virginia State Bd. of Pharmacy, 425 U.S. at 756.

298 Elrod v. Burns, 427 U.S. 347, 362 (1976). 
The burden should be on the CIA to prove that its restrictions further a compelling state interest and that no less restrictive alternatives exist. ${ }^{299}$

The GIA should be able to surmount the initial hurdle. Few can question the Snepp majority's assertion that " $[\mathrm{t}]$ he Government has a compelling interest in protecting ... the secrecy of information important to our national security." 300 Prior case law supports this claim beyond a doubt. ${ }^{301}$

The Snepp Court went further, however, and added that there is a compelling interest as well "in protecting . . . the appearance of confidentiality so essential to the effective operation of our foreign intelligence service." 302 In this respect the Court appears to be flatly wrong. ${ }^{303}$ To understand why, one must first understand what is meant by denominating an interest "compelling." As implied by the structure of the strict scrutiny test, compelling interests are those which are so important that their effectuation justifies curtailment of first amendment freedom. The inherent logic of strict scrutiny incorporates a belief that so long as the state treads

299 Cf. Nebraska Press Ass'n v. Stuart, 427 U.S. 539, 565 (1976) (gag order constitutional only if no less restrictive alternative available).

In Elrod, Justice Brennan mentioned a third element, a requirement that the state show, presumably on a case-by-case basis, that "the benefit gained . . . outweigh[s] the loss of constitutionally protected rights." 427 U.S. at 363 (footnote omitted). By contrast, the test proposed in the text subsumes such a weighing in the determinations of "compelling" interests; by definition, the realization of these goals (by the least restrictive route) justifies suppression. The two-step analysis thus utilizes categorical, rather than particularized, judgments of relative harm and benefit. It is generally agreed that this mode of abstract decision-making is more hospitable to free speech, for it insulates first amendment liberties from transient periods of political repression. See J. Ely, Democracy and Distrust 105-16, 233 n.27 (1980); L. TruBE, supra note $210, \$ 12-2$, at 580-84.

300 Snepp v. United States, 444 U.S. 507,509 n.3 (1980) (per curiam).

301 See Chicago \& Southern Air Lines, Inc. v. Waterman Steamship Corp., 333 U.S. 103, 111 (1948); United States v. Curtiss-Wright Export Corp., 299 U.S. 304, 320 (1936); E. W. Bliss Co. v. United States, 248 U.S. 37, 46 (1918). But see Linde, Couts and Censorship, 66 MinN. L. Rev. 171 (1981).

302444 U.S. at 509 n.3.

${ }^{303} \mathrm{~A}$ similar argument was advanced in Landmark Communications, Inc. v. Virginia, 435 U.S. 829 (1978) to justify a Virginia statute which outlawed the disclosure of all confidential information that had come before a state commission charged with investigating allegations of judicial misconduct. It was argued that punishment enhanced the confidentiality of the proceedings, and that this in turn furthered the interest in "protecting the reputation of the judges, [and] . . . maintaining the institutional integrity of its courts . ..." Id. 841 . The Court found little merit in this argument: "injury to official reputation is an insufficient reason "for repressing speech that would otherwise be free." Id. 841-42 (citing New York Times Co. v. Sullivan, 376 U.S. 254, 272-73 (1964)). The Court's summary dismissal of this contention is significant, for an appearance of dignity and honesty is arguably as important to the successful operation of a judiciary as an appearance of confidentiality is to the successful gathering of intelligence. 
no more heavily than is necessary on free speech, society's net welfare is advanced by policies that further the compelling interest; it is assumed that the attainment of these interests is such a valuable goal that any harm caused by incidental, yet necessary, inroads on the first amendment pales in comparison.

Thus, if the interest in preserving an "appearance of confidentiality" is indeed compelling, free speech rights are protected solely by the subsidiary requirement that the government act only in the least restrictive manner. In this case, however, such protection is woefully inadequate. Consider the reasons adduced to support the allegedly "compelling" need for the desired "appearance." As noted previously, the CIA's position is that friendly foreign intelligence services refuse to share sensitive information when not first convinced that the CIA can safeguard its secrecy. Efforts geared to erecting the "appearance," by enhancing the CIA's credibility, thus allow the agency to conduct more profitable "liaisons." But this, of course, is true only to the extent that the created "appearance" satisfies foreign specifications. Only an "appearance of confidentiality" that in fact keeps foreign intelligence agencies "happy" is sufficient. Hence, if this goal is "compelling," a free speech restriction passes constitutional muster subject only to the requirement that it be the least intrusive method of keeping the CIA's foreign partners complacent. A challenger could always claim that a given restraint was not the least restrictive, but the challenge would succeed only upon proof that a second restraint was both less intrusive and capable of satisfying the desires of foreign intelligence agencies. Yet how could the latter point ever be established if the affected foreign agency heads testified that the challenger's proposed substitution was unacceptable? Unless we would be willing to follow the dubious course of permitting court challenges to the bona fides of such statements-clearly a step highly inconsistent with the goal of not antagonizing foreign allies ${ }^{304}$ we would be forced to deem the offered testimony conclusive on the issue of acceptability. ${ }^{305}$ In the end, American civil liberties would

304 Cf. Banco Nacional de Cuba v. Sabbatino, 376 U.S. 398 (1964) (foreign policy considerations precluded Court from judging legality of Cuban expropriation).

305 These dynamics can be observed in Snepp itself. In upholding the district court's finding that Snepp had caused the CIA irreparable injury, the Court relied heavily on the testimony of Admiral Turner, who merely related the wishes and desires of unnamed foreign agencies:

[W] have had a number of sources discontinue work with us. We have had more sources tell us that they are very nervous about continuing work with us. We have had very strong complaints from a number of foreign intelligence services with whom we conduct liaison, who have questioned 
live under the thumb of foreign veto.306 The ultimate censor would be not a court, but rather an entity such as SAVAK, the former Shah of Iran's secret police, an organization not noted for its understanding of civil rights. Such delegation would be intolerable. ${ }^{307}$

whether they should continue exchanging information with us, for fear it will not remain secret. I cannot estimate to you how many potential sources or liaison arrangements have never germinated because people were unwilling to enter into business with us.

Snepp, 444 U.S. at 512-13. The Court's willingness to rely on this testimony is nothing short of remarkable. Not only was it conclusory and self-serving, but it was essentially untested as well. The trial court had drastically limited Snepp's attempt to cross-examine Admiral Turner, id. 523 nn.12-13 (Stevens, J., dissenting), a fact the majority conveniently ignored. Such a casual reading of the record strongly suggests that the Court is predisposed to give the CIA's foreign partners whatever they want, or whatever the CIA says they want, and with few questions asked. But see Landmark Communications, 435 U.S. at 841, wherein the Court rejected an analogous "appearances" argument, see supra note 303 , with the terse rejoinder: "The Commonwealth has offered little more than assertion and conjecture to support its claim that without criminal sanctions the objectives of the statute would be seriously undermined."

306 Of course, foreign reactions often determine whether or not speech is "protected." Disclosures of troop transport sailing dates, for example, are punishable solely because of a feared, foreign-based harm. See 18 U.S.C. $\$ 794$ (b) (1976); Near v. Minnesota ex rel. Olson, 283 U.S. 697, 716 (1931). Thus, in a sense, the concept of "foreign veto" is not unknown. What distinguishes the situation sketched in the text from this scenario is that in the latter, the "foreign veto" is itself subject to effective U.S. court review. Sailing date revelations are proscribable only because it has been determined internally and categorically that free speech must give way when imminent danger to innocent human life hangs in the balance. By contrast, once it is determined that appeasing foreign intelligence officers is a compelling goal of government, explicit foreign endorsements of a given restraint receive no effective judicial scrutiny at all.

Might not the best solution be to allow for some balancing? The courts might hold, for example, that inquiry does not cease upon a determination that a given restraint creates the needed "appearance of confidentiality" in the least restrictive way possible. Instead, the courts might then weigh, on a case-by-case basis, the value of obtaining this end versus the burden it imposes on free speech. Formally, this approach would cure the problems of delegation that have been discussed, for a judicial check on foreign demands would now exist. Nevertheless, this is not enough. All national security claims, by their nature, possess a "visage of overriding importance." Brown v. Glines, 444 U.S. 348, 369 (1980) (Brennan, J., dissenting). In a case-by-case, as opposed to categorical, weighing process, this factor is likely to predominate. See generally supra note 299 . The danger is accordingly too great that this type of judicial check will disintegrate into nothing, thereby leaving the inherent problems of delegation unremedied.

307 See Fernandez v. Wynn Oil Co., 653 F.2d 1273, 1276-77 (9th Cir. 1981) (foreign customer preferences do not justify sex discrimination in employment; opposite rule "would allow other nations to dictate discrimination in this country. No foreign nation can compel the non-enforcement of Title VII here") (footnote omitted). See also Sumitomo Shoji America, Inc. v. Avagliano, 102 S. Ct. 2374 (1982) (subsidiary of Japanese company, incorporated in United States, is subject to American statutes banning employment discrimination on the basis of sex and national origin). The Constitution itself might be read as outlawing any notion that the greater social good lies in acceding to foreign demands that internal political dialogue cease. To be sure, the text of the Constitution nowhere expressly bars delegations of this type. It is likely, however, that the framers thought the 
In rebuttal, one might argue that the absence of judicial review does not necessarily grant foreigners carte blanche. After all, a foreign demand for a restraint is only that; implementation requires the cooperation of internal decision-makers. Thus, if we could trust the CIA to approve only those demands that do not intrude heavily upon first amendment liberties, much of our worry would disappear. Unfortunately, there is little basis for this trust. Nonjudicial determinations of first amendment contours have been wrong before, ${ }^{308}$ and there is little reason to believe that they will not be again. Indeed it is hard to envision any incentive propelling the CIA towards a scrupulous defense of free speech. ${ }^{309}$ Yet it is easy to envision the opposite inclination. A foreign agency's desire for security precautions might, for example, mesh quite nicely with a CIA desire to monitor the speech of its dissident former employees. The postulated nonjudicial check is in all probability no check at all.

In sum, of the two asserted compelling interests, only the first, the interest in preventing injurious disclosures of sensitive, defenserelated data, is legitimate. ${ }^{310}$ Accordingly, the restraints embodied in the CIA's secrecy agreement should be upheld only if necessary to effectuate this goal, that is, only if no other less restrictive method adequately insures that former agents will refrain from such behavior. At first blush, it would seem that the CIA must lose, for, as we saw in part III, all citizens, private individuals and secret agents alike, are already subject to two potential restraints, espio-

proposition so basic that they saw no need to spell it out. The Constitution, after all, was written by men who but a few years earlier had taken up arms in order to escape the mandates of a foreign sovereign. It is unlikely that these very same men subsequently authored a document sanctioning the identical evil.

Moreover, various provisions of the Constitution affirmatively reflect a desire that governmental decision-making take place free of the influences of foreign ideology. Only individuals who have been citizens during the seven years preceding an election are eligible for membership in the House of Representatives. U.S. CoNs'r. art. I, $\$ 2, \mathrm{cl}$. 2. An analogous nine-year requirement limits the pool of potential senatorial candidates. Id. $\$ 3, \mathrm{cl}$. 3. The President must be both a natural-born citizen and an individual who has actually resided in the U.S. during the fourteen years immediately preceding the election. Id. art. II, $\S 1$, cl. 4. Furthermore, no federal officer can accept a foreign title while still in office without the consent of Congress. Id. art. I, $\$ 9$, cl. 8. All of these provisions insure that state decision-making is conducted by individuals who can be presumed responsive to domestic ideology. It would seem entirely consistent with this scheme to impose on these officials the obligation of maintaining fidelity to these beliefs.

308 See, e.g., United States v. Robel, 389 U.S. 258 (1967).

309 See supra text accompanying notes 271-79.

310 Since Snepp was no longer a CIA employee at the time of suit, the CIA asserted no interests unique to an ongoing employer-employee relationship. See generally Pickering v. Board of Educ., 391 U.S. at 566-67. 
nage law ${ }^{311}$ convictions and New York Times ${ }^{312}$ injunctions. To be sure, the protection afforded by these measures is less than perfect. Because successful prosecution under the espionage laws often requires proof of bad motive, ${ }^{313}$ most well-meaning disclosures, no matter how injurious, are exempt from their reach. Injunctions can be sought if the state obtains advance warning of a speaker's plans, but such warning will be the exception, not the rule. ${ }^{314}$ Furthermore, even if advance warning is obtained, the state's troubles are hardly over, for New York Times sets an extremely high standard to reach. ${ }^{315}$ Yet notwithstanding these drawbacks, we concluded in part III that when the speaker is a private citizen, these measures are adequate protection and the state is entitled to no more. The costs of imposing "more," in particular the restraints the CIA here seeks, were viewed as too heavy.

Thus, if the CIA hopes to sustain its contracts, it first must prove that secrecy-agreement signers are different, that they threaten national security with significantly greater dangers that can be neutralized only with correspondingly stronger measures. More precisely, the CIA must show either that signers are more likely than others to reveal sensitive information or that the harms flowing from a given revelation are greater when the speaker is a signer.

As for the relative probabilities of disclosure, three subordinate factors seem pertinent: general propensity to reveal, ability to effectuate this propensity, and the degree to which adverse action is deterred by the fear of conviction or injunction. Analysis along the propensity axis is problematic. On the one hand, secrecy-

311 In addition to 18 U.S.C. $\$ 793(\mathrm{e})$, discussed supra at text accompanying notes 157-89, the basic provision criminalizing speech (as opposed to pure espionage) is 18 U.S.C. $\$ 793(\mathrm{~d})$ (1976). This law is identical in all material respects to section 793(e) except that the former applies to defendants "lawfully having possession of" the information, e.g., CIA agents, while the latter covers those having "unauthorized possession." Both sets of individuals are subject as well to several narrow prohibitions outlawing specific types of disclosures. See 18 U.S.C. $\$ 794$ (b) (1976) (troop movements); id. $\$ 797$ (photographs of defense installations); $i d$. $\$ 798$ (classified communications systems data); 42 U.S.C. $\$ 2274$ (1976) (Atomic Energy Act Restricted Data); See also Intelligence Identities Protection Act, Pub. L. No. 97-200, 96 Stat. 122 (1982) (criminalizing the disclosure of an undercover agent's name). Government employees, moreover, fall within the reach of two other narrow prohibitions. See 18 U.S.C. $\$ 952$ (1976) (diplomatic codes); 42 U.S.C. $\$ 2277$ (1976) (restricted data); cf. 50 U.S.C. $\$ \$ 781-783$ (1976) (dealing with pure espionage activities). For the purposes of analysis, these more limited statutes will be disregarded.

312 New York Times Co. v. United States, 403 U.S. 713 (1971) (per curiam). 313 See supra text accompanying notes 167-87.

314 See New York Times, 403 U.S. at 733 (White, J., concurring).

$315 \mathrm{Cf}$. Developments, supra note 187 , at 1240 (formulations of standards in Brennan and Stewart concurring opinions "come very close to absolute prohibition on prior restraint"). 
agreement signers do not comprise a random subset of the population. Rather they form a select group united by the unique access to classified material each member enjoys. The significance of this lies in the fact that not everyone is eligible for membership in such a group. A person is eligible for access to classified information only if "a determination of trustworthiness has been made by agency heads or designated officials." ${ }^{16}$ One thus might argue that a regime of secrecy agreements makes absolutely no sense, since it imposes added burdens only on those who have been officially certified as trustworthy. But, of course, an initial determination of trustworthiness cannot insure that an individual's propensities will never change. Suppose an agent's policy viewpoint is later rejected by a superior: The agent might conclude that neither the CIA nor the superior warranted loyalty any longer. Disclosure of the secret information underlying the rejected viewpoint could in turn be seen by the agent not as a breach of trust, but as a legitimate method of both correcting erroneous policy ${ }^{317}$ and settling personal scores. ${ }^{318}$

Analysis of propensity may thus be ultimately indeterminate, but the same surely cannot be said of an inquiry focusing on access. The CIA agent who is inclined to reveal defense-related information is much "better off" than his or her private-citizen counterpart. The private citizen, if the classification system is observed, has no way of obtaining anything dangerous to reveal. Legally, the citizen has no right to any classifiable information. ${ }^{319}$ The passive restraint of nondisclosure thus shields the state from harm. But no such restraint hinders CIA agents. Secrecy agreements, by their nature, embody state renunciations of the right to withhold. CIA agents, unlike private citizens, are privy to classifiable data.

Disclosure-minded agents are, moreover, less likely to be restrained by the fear of criminal prosecution. For one thing, being "insiders," secrecy-agreement signers are more likely than average citizens to be aware of the general limitations that hinder governmental efforts to prosecute or enjoin. They may also be aware of the unique problems the state faces in trying to prosecute insiders. The espionage laws, as we have seen, often base criminality on whether or not the defendant had "reason to believe" that disclosure would be injurious. In theory, these laws should apply with

${ }^{316}$ Exec. Order No. 12,356, $\$ 4.1$ (a), 47 Fed. Reg. 14,874, 14,880 (1982).

${ }^{317}$ See Developments, supra note 210 , at 1207.

${ }^{318}$ See Comment, Enforcing the CIA's Secrecy Agreement Through Postpublication Civil Action: United States v. Snepp, 32 StaN. L. Rev. 409, 415 (1980).

319 See supra note 197. 
greater force against insiders. For if information appears innocuous to the layman but has great significance in the eyes of an intelligence professional, only disclosure by the latter is subject to prosecution. ${ }^{320}$ But prosecution is only a possibility, and a remote one at that. Under these circumstances, an actual trial would require revealing in open court exactly how and why the challenged disclosure was not innocuous. The government would have to expose to public view the special and, by hypothesis, secret background information possessed by the speaker. It would further have to reveal exactly why it believes that this background data warrants placing an "injurious" label on the challenged disclosure. Obviously the additional harms generated by these testimonial disclosures can often outweigh any gain the government hopes to obtain through conviction. The state may thus find that "it has no remedy at all." ${ }^{221}$ To the extent that secrecy-agreement signers understand this reality, a likely eventuality given their "insider" status, these individuals will know as well that, should they so desire, they are in a unique position to harm national security without fear of legal sanction. ${ }^{322}$

320 See generally Edgar \& Schmidt, supra note 167, at 1042.

321 Snepp, 444 U.S. at 515; see generally Edgar \& Schmidt, supra note 167, at 978. Just recently, the Justice Department decided not to prosecute Miguel Nassar Haro, a Mexican national implicated in an investigation of an $\$ 8,000,000$ stolen-car ring. Mr. Nassar had previously served as chief of Mexico's national police. Prosecution was thought too risky since it "could expose and jeopardize important international intelligence connections." N.Y. Times, Mar. 30, 1982, at B-14, col. 2.

322 Prior to the passage of the Classified Information Procedures Act, Pub. L. No. 96-456, 94 Stat. 2025 (1980), prosecution of insiders was further hindered by the related problem of "graymail," the phenomenon of defendants forcing the state "to back down in the face of a threat to disclose national security information" during the course of trial. Lacovara, Resolving the "Disclose or Dismiss" Dilemma, Nat'l L.J., May 14, 1979, at 19, col. I; see generally Comment, supra note 318, at 420 . The potential leverage was so great that an insider who disclosed sensitive information could often derail his prosecution simply by threatening to make further revelations of the same character. This created a

perception that government officials and private persons with access to military or technological secrets have a broad de facto immunity from prosecution for a variety of crimes. This perception not only undermines the public's confidence in the fair administration of criminal justice, but it also promotes concern that there is no effective check against improper conduct by members of our intelligence agencies.

S. Rep. No. 823, 96th Cong., 2d Sess. 4, reprinted in 1980 U.S. Code Cong. \& AD. News 4297 (emphasis added) (citing testimony of Assistant Attorney General Philip Heymann).

The Act changed all this. Section 5 requires defendants to give notice before trial of their intent to disclose classified data. Section 6 authorizes pre-trial hearings at which the data's relevancy can be ascertained, as well as the defendant's ability to conduct a defense without it. At government request, these hearings can be held in camera. If the court finds that the defendant is entitled to the use of the information in question, the government may still forestall its introduction by seek- 
Compounding this problem is the reality that defense-related disclosures are more dangerous when made by a CIA agent. When a current or former insider talks, people listen and believe. ${ }^{323}$ Conversely, listener skepticism can mitigate the damage caused by an outsider's revelation of the very same information. . $^{324}$

Thus, our initial surmise, that the CIA is entitled to nothing more than what New York Times and the espionage laws now give it, is wrong. Secrecy-agreement signers and private citizens are not similarly situated. The GIA is consequently entitled to those additional restraints that counteract the imbalance in the least restrictive manner possible.

First there is the imbalance in access. To understand its implications, it is perhaps useful to divide the universe of national security data into three components. At one end of the spectrum is information which is not classifiable under existing Executive Order. This data can be obtained as of right from the government via the Freedom of Information Act ${ }^{325}$ and, once obtained, disseminated without criminal penalty. At the other end of the spectrum is information the dissemination of which would threaten a "clear and present" danger. This information can not be legally

ing leave to stipulate to the facts the evidence would tend to establish. Alternatively the government can ask for an order limiting the defendant to the introduction of summaries of the data. These motions can be denied only if the defendant would thereby be denied a fair trial. If the court rules again for the defendant, and the government continues to object to revelation, the court can then, but only then, dismiss the indictment. It need not, however, if more limited relief would better serve the interests of justice.

The Act does little by contrast for the problems the government faces in presenting its own case. While section $8(\mathrm{~b})$ authorizes the court to take measures which will prevent the "unnecessary disclosure of classified information," this provision in no way aids a prosecution in which sensitive information underlies the very heart of the government's case.

323 Chief Judge Haynsworth recognized this difference in formulating the "public domain" exception to his general rule barring publication of classified information by secrecy-agreement signers:

Information, though classified, may have been publicly disclosed. If it has been, Marchetti should have as much right as anyone else to republish it. Rumor and speculation are not the equivalent of prior disclosure, however, and the presence of that kind of surmise should be no reason for avoidance of restraints upon confirmation from one in a position to know officially.

United States v. Marchetti, 466 F.2d 1309, 1318 (4th Cir.) (emphasis added), cert. denied, 409 U.S. 1063 (1972); see also Pickering, 391 U.S. at 572.

324 The CIA would probably argue that agent disclosures are more dangerous for the additional reason that they cause foreign allies to question the safety of sharing information with the Agency. Because this contention merely restates the "appearance of confidentiality" argument, it must be denied controlling significance once again. An opposite conclusion contains the seeds of intolerable delegation. See supra text accompanying notes 302-09.

325 See 5 U.S.C. $\$ 552$ (1976). 
obtained by private citizens ${ }^{326}$ and its revelation at least arguably could be made criminal. In between these two extremes is classifiable data that a private citizen can legally reveal. Here, the interest in secrecy is protected solely by the power of the state to refuse disclosure. ${ }^{327}$ Thus, in this intermediate area, the state has no protection at all against secrecy-agreement signers; they are, by definition, exempted from the rules of nondisclosure. The state can protect itself in this instance only by outlawing disclosures by agents of information they had no legal right of access to but for their employment. ${ }^{328}$ All agent disclosures of classifiable ${ }^{329}$ infor-

326 See supra note 197.

327 See id.

328 See Landmark Communications, 435 U.S. at 837 \& n.10. Cf. 42 U.S.C. $\$ 2000 \mathrm{e}-5$ (b) (1976) (forbidding disclosures by officers and employees of the Equal Employment Opportunity Commission of information learned during confidential conciliation proceedings).

329 In permitting agents to disclose secret, currently classifiable information which has not yet been actually classified, the Knopf court was actually more generous than it need have been. See Knopf, 509 F.2d at 1367. Since private citizens cannot obtain such data, see Lesar v. United States Dep't of Justice, 636 F.2d 472 (D.C. Cir. 1980) (properly classifiable documents not obtainable even though not classified until FOIA request made), the imbalance in access applies with full force to this category of information. For a refinement of this analysis, see infra note 330 .

There is no theoretical imbalance, by contrast, with respect to classified data that is not classifiable. All members of the public have a right to inspect this information. But one might argue that there is a more subtle imbalance present. The integrity of the classification system depends upon ordered, bureaucratic declassification decisions. If all CIA agents are free to bypass established channels and raise the declassification issue in defense, this integrity is diminished. Of course, the same holds true when a private citizen covertly obtains classified information, publishes, and then argues lack of "reason to believe" in response to a prosecution under $\$ 793(\mathrm{e})$. See supra text accompanying notes 162-66. But this danger is slight in comparison to that posed by agents who have much greater access to classified material. One thus might wish to deprive agents of the "lack of classifiability" defense in order to induce them to litigate these matters in advance. Cf. Scarbeck v. United States, 317 F.2d 546 (D.C. Cir. 1962), cert. denied, 374 U.S. 856 (1963) (government employee cannot knowingly transmit classified information to Communist agent and then argue lack of classifiability; decision predates the FOIA; in 1962, the access imbalance applied to all classified documents).

This suggestion should be rejected. Given the fact of massive overclassification, see supra text accompanying note 280 , agents would almost certainly have to clear much of their CIA-related writing with the Agency in advance. Thus, most of the dangers of prepublication review would have to be suffered solely to preserve the administrative scheme contemplated by the executive. Such a tradeoff cannot be tolerated. There is no compelling reason to bolster a given administration procedure simply for the sake of having it. If the "integrity" of the classification system is indeed worth preserving, it is not because it has some intrinsic worth, but rather because its procedures best insure the result for which it was designed: the nondissemination of classifiable information. Therefore the true inquiry should be: does the need to prevent classifiable disclosures justify a de facto requirement that former agents submit for prior review virtually all CIA-related communications? As argued infra at text accompanying note 339 , it does not. Former agents therefore should not be subject to punishment for revealing classified information that is not properly classifiable. 
mation learned while at the CIA can thus be rendered illegal..$^{330}$ The CIA's second main restraint is by and large constitutional. ${ }^{331}$ The CIA's methods of enforcement, however, are inappropriate. Since neither contract damage nor constructive trust relief requires any proof of scienter, inadvertent disclosures can fall within the ambit of these restraints. ${ }^{332}$ The likely effect of this is to induce agents to guard their words closely, for otherwise they risk the penalties levied on accidental disclosure. In this process, border-

330 So long as the information was properly classified at the time the agent learned of it, it should generally be irrelevant whether it remains classifiable under an executive order that is subsequently promulgated. Current FOIA doctrine holds that private citizens can obtain this information only if it has been incorrectly reclassified pursuant to the latter order. See supra note 81 . In the absence of this exception, the imbalance in access remains.

Different considerations might apply if at the time the information was obtained it was not actually classified, but was nevertheless secret and classifiable under the executive order then in effect. If actual classification later took place under the terms of this initial order, the enactment of a second more liberal order would affect the imbalance in access in the same way as above. If, however, the information was never classified before the agent's disclosure, see supra note 329 , or if it was classified only after the second order had been promulgated, see supra note 81, the terms of the latter would govern any request made under the FOIA. Thus if the data did not warrant protection under the newer order's provisions, the enactment of the second order would effectively neutralize the initial imbalance in access.

One final variation deserves comment. An agent should not be subject to punishment for disclosing information that currently merits classification if such data was neither properly classified at the time he learned of it at the CIA nor classifiable under the terms of the executive order then in force. No but-for tie can be drawn between the agent's possession of this knowledge and his signing a secrecy agreement.

${ }^{331}$ To the extent that the CIA's actual ban on revealing classified and classifiable information applies to all such data, and not simply that obtained while employed at the Agency, see supra note 82 , it is clearly overbroad. Once an agent resigns from the CIA, the imbalance in access ceases.

In some instances this may not be true in fact. The "old boy" network may keep some former agents abreast of current developments even after retirement. However, only dissidents such as Snepp are likely to be targets of actual CIA enforcement actions. Since they are most probably not "old boys" themselves, it would be perverse if their rights were reduced on such a theory of continuing access. To do so would penalize them for advantages enjoyed solely by others.

$\mathbf{3 3 2}$ Constructive trust relief is inappropriate for a second reason. Under the circumstances of cases like Snepp, allowing this remedy essentially entitles the government to an accounting of royalties: The state gains a de facto copyright interest in the information revealed. Clearly, such a result cannot be countenanced. Congress has itself explicitly decided that the government should have no such property right. 17 U.S.C. $\$ 105$ (1976); see Brief of the Reporter's Committee For Freedom of the Press, Amicus Curiae, Snepp v. United States, 444 U.S. 507 (1980). Prior cases that hold a government employee's relationship with the state to be fiduciary are hence inapposite. In each, the government entrusted the employee with the care of its rightful property. See, e.g., United States v. Carter, 217 U.S. 286 (1910) (defendant given control of U.S. funds necessary for harbor improvement); United States v. Kearns, 595 F.2d 729 (D.C. Cir. 1978) (defendant employed as head of government credit agency); United States v. Drumm, 329 F.2d 109 (1st Cir. 1964) (defendant dispensed commercially valuable inspection labels); but see Comment, supra note 318 , at 422-23. 
line, yet protected, speech is likely to be abandoned. ${ }^{333}$ The CIA's proposed remedies thus sweep too far. They are not closely enough tailored to the end they may legitimately seek.

For these reasons, the state should be obligated to show some degree of scienter. At the very least, negligence with respect to the fact of classifiability must be established. If it is, the CIA should have the power to demote or dismiss the offender. ${ }^{334}$ But clearly this cannot be all; neither the threat of demotion nor the threat of dismissal deters anyone who, like Snepp, relinquishes his position before he writes. The state must thus have at its disposal some form of post-employment sanction as well. For this purpose, both monetary penalties and prison terms seem appropriate..$^{335}$ The CIA should not, however, be able to enjoin all agent revelations of this nature. The bias of the injunctive forum in favor of the government's position in national security cases remains just as formidable as before. The danger accordingly exists that if injunctions become available, at least some revelations will be deemed classifiable and thus enjoinable, ${ }^{330}$ even though they would not be so labelled in an after-the-fact criminal forum. Since it is only in the criminal proceeding that harm is judged on the basis of observed fact rather than speculation, ${ }^{337}$ it is likely that the availability of injunctive relief would overcompensate for the actual harm to national security that the imbalance in access may cause. ${ }^{338}$

Nor should the access imbalance justify a system of prepublication review. Information "relating to the CIA" can fall within

333 See Smith v. Califormia, 361 U.S. 147, 152-54 (1959).

334 See 50 U.S.C. $\$ 401$ (Supp. II 1978); see generally Pickering v. Board of Educ., 391 U.S. 563, 570 n.3 (1968); Hill, Defamation and Privacy Under the First Amendment, 76 Colum. L. Rev. 1205, 1294 n.424 (1976).

335 Termination of retirement benefits, see 5 U.S.C. $\$ 8312$ (1976), is an additional potent and appropriate sanction.

336 Of course, since the CIA cannot enjoin speech that it cannot punish after the fact, see supra text accompanying note 146, no injunction should issue unless the court first finds that the speaker would be acting negligently with regard to the possibility that the proposed speech was classifiable in nature. Clearly, however, if a court first holds in an injunctive proceeding that various items of information are classifiable, the speaker from that point on has sufficient notice of how the proposed revelations are viewed. So long as the CIA seeks injunctions of the type directed towards a particular communication, any success it has in proving classifiability will (if such injunctions are allowed) establish its right to relief.

337 See supra note 210.

338 The injunction discussed in the text is one directed towards a specific revelation. A future-oriented order, one directing an agent to refrain from all future criminal disclosures of classifiable material, would overcompensate to an even greater degree, given the extensive amount of pre-speech court scrutiny such an order is likely to induce. See supra text accompanying notes 211-23. 
any one of the three major categories of national security data. Yet, as we have seen, the imbalance is mainly present in only one of them. The fit between ends and means is once again too loose. ${ }^{339}$ Tentatively, then, the CIA must content itself with a reduced threshold for subsequent punishment. But if the state is to employ this weapon, it still must prove classifiability, and this may require sensitive disclosures as before. Simply lowering the standard for criminal liability does not eliminate the need to rectify the imbalance in deterrent effect. However, the danger that sensitive data will be publicly disclosed in the course of trial can be greatly, if not completely, reduced by the simple expedient of holding the pertinent portions of the case in private. Of course, given the defendant's sixth amendment right to a public trial, 340 this "simple

339 Even if this problem were formally corrected, i.e., even if an agent were required to submit to prior review only those revelations that are classifiable, overinclusiveness would in practice still result. The contours of classifiability, as we have seen, are not self-defining. An agent's understandable urge to play it safe would in all probability induce him to submit more than was necessary.

But isn't the answer to this objection to require scienter as before? See generally Comment, supra note 89, at 704-05. What objection can there be to punishing an agent who unilaterally and negligently publishes classifiable information? Presumably none. Such publication can be rendered illegal whether or not "unilateral." The issue is not whether any punishment is allowable, but rather whether the "unilateral"/non-"unilateral" distinction is a valid basis for increasing the degree of the sanction. It is not. The only possible reason for viewing the "unilateral" speaker as being more culpable is that, by denying the CIA an advance screening, he or she effectively deprived the Agency of any real opportunity to obtain a New York Times injunction. See id. But even if this is deemed a legitimate ground for concern, the proposed restraint still sweeps too far. The government has no right at all to enjoin most disclosures that can merely be shown to be classifiable, even when the speaker is a former CIA agent. See supra text accompanying notes 336-38. As to the bulk of the restrained speech, the CIA thus never had any right in the first place to obtain an injunction. The failure to presubmit effectively deprived the agency of nothing.

The very most this CIA argument can support is a restraint tied more closely to its rationale. A law that seemingly meets this standard would be one that requires a former agent to presubmit a CIA-related communication only when the author should reasonably understand it to contain information that can be enjoined. Comment, supra note 89 , at 704-05. What is troubling about this proposal is that its logic extends fully to the private citizen context. A private citizen's failure to presubmit under analogous circumstances would equally deprive the CIA of an opportunity to enjoin material it probably has a "right" to suppress. More fundamentally, if one accepts the basic argument underlying this reasoning-that the government has not only a "right" to enjoin known material of a given sort, but $\dot{a}$ "right" as well to learn of all revelations that are at least to some degree potentially enjoinable-one must also accept additional state behavior that is questionable at best. Surreptitious surveillance of dissidents, for example, might become justifiable under such a scheme. Because of these dangers, even the most limited prepublication restraint that has been postulated should be rejected.

340 The press and public have a similar first amendment right as well. See Richmond Newspapers, Inc. v. Virginia, 448 U.S. 555 (1980). It is subject to at least as many qualifications as is the defendant's sixth amendment privilege. See L. TruBe, supra note $210, \$ 12-11$, at 629 n.28. 
expedient" raises constitutional problems of its own, but it is well recognized that this right, like others, is not absolute. ${ }^{341}$ Trials have been closed, over a defendant's objection, in order to protect the privacy of a young rape victim, ${ }^{342}$ in order to maintain courtroom order, ${ }^{343}$ and in order to protect a government witness from threatened harassment. ${ }^{344}$ More importantly, closure orders have also issued in order to preserve the confidentiality of various pieces of information. Thus, the need for confidentiality has justified closing courtroom doors during a discussion of the government's "hijacker profile." ${ }^{445}$ Similarly, an undercover agent's identity need not be revealed in public. ${ }^{346}$ Commercial "trade secrets," one court has further speculated, might also merit protection. ${ }^{347}$ Glearly, the need to protect national security secrets is just as compelling as the need to safeguard industrial formulae. Trial closure in national security cases is proper, the sixth amendment notwithstanding. ${ }^{348}$

The special problems that hinder prosecutions of insiders are thus not unavoidable roadblocks. The state need not fear its own legal machinery. Once prosecutors believe this and start prosecuting, the word should quickly spread throughout the intelligence community. If so, the imbalance in deterrence will be greatly redressed.

Prepublication review, by contrast, attacks this problem in an extremely imprecise way. It arguably furthers deterrence by creating a separate offense-publishing without approval-the proof of which requires no sensitive disclosures. Under this regime, the government can seek without fear some punishment for an injurious

341 See, e.g., United States ex rel. Lloyd v. Vincent, 520 F.2d 1272, 1273-74 (2d Cir.), cert. denied, 423 U.S. 937 (1975) (citations omitted).

342 See, e.g., Harris v. Stephens, 361 F.2d 888, 891 (8th Cir. 1966), cert. denied, 386 U.S. 964 (1967). See also Globe Newspaper v. Superior Court, 102 S. Ct. 2613 (1982) (states may not automatically exclude press from trials involving sex crimes against minors).

343 See, e.g., United States ex rel. Orlando v. Fay, 350 F.2d 967, 971 (2d Cir. 1965), cert. denied, 384 U.S. 1008 (1966).

344 See, e.g., United States v. Hernandez, 608 F.2d 741, 747 (9th Cir. 1979). 345 See United States v. Bell, 464 F.2d 667, 670 (2d Cir.), cert. denied, 409 U.S. 991 ( 1972 ).

346 See United States ex rel. Lloyd v. Vincent, 520 F.2d 1272, 1274 (2d Cir.), cert. denied, 423 U.S. 937 (1975).

347 Stamicarbon, N.V. v. American Cyanamid Co., 506 F.2d 532, 540-42 (2d Cir. 1974).

348 While discussing the boundaries of the public's first amendment right to an open trial, see supra note 340 , Justice Brennan voiced identical thoughts: "[N]ational security concerns about confidentiality may sometimes warrant closures during sensitive portions of trial proceedings, such as testimony about state secrets." Richmond Newspapers, 448 U.S. at 598 n.24 (Brennan, J., concurring in judgment). 
unilateral disclosure. But of course, it can seek this same punishment even if the unilateral disclosure is benign. Conversely, the restraint is useless in prosecuting harmful disclosures if the author has in fact presubmitted the publication. ${ }^{349}$ Prepublication review is closely matched with the goal of deterring unilateral publication per se. It only incidentally helps deter injury to national security secrets.

Similarly, the deterrence imbalance would be attacked in only the most haphazard way by a decision authorizing either CIA injunctions against mere classifiable disclosures or CIA prosecutions of agents who disclose such material in the absence of scienter. These measures would increase the overall level of deterrence by simply rendering more agent behavior actionable. The latter remedy alone would be especially potent in this regard. ${ }^{350}$ However, neither solution would address the underlying cause of the imbalance it purportedly corrects. Only the remedy of trial closure does this. Such highly tailored relief should not be disregarded in favor of more sweeping measures in the absence of convincing evidence that more is truly needed.

Finally, there is the imbalance resulting from the agent's greater credibility. Here, there is little the law can do in a remedial sense. Mass perceptions of relative credibility are simply not amenable to legislative alteration. The law should, however, be structured in such a way that it reacts rationally to these differences. Thus, in passing on injunctive requests, the judiciary should be sensitive to the importance of who is doing the talking. More concretely, the dangers of enhanced credibility should be factored into the process of determining whether or not an agent's disclosure "surely" threatens "direct, immediate and irreparable damage." 351 Agents who are convicted disclosers, moreover, should be subjected to harsher penalties-stiffer fines, longer prison terms-than those applied to guilty private citizens.

Considerably more sweeping is the CIA's notion that all disclosures by agents of classified and classifiable information should

349 This "Ioophole" could be partially closed by granting the CIA the added power to enjoin agent disclosures of merely classifiable information. There would then be fewer instances in which a harmful disclosure would actually follow prior submission. Surely, however, a serious restraint on first amendment freedom such as prior review cannot be made more tolerable by the addition of even more restrictions. But of. Metromedia, Inc. v. City of San Diego, 453 U.S. 490, 510-11 (1981) (hinting that a total ban on billboards might be constitutional even though a more limited content-based ban was not).

350 See supra text accompanying notes 332-33.

351 New York Times, 403 U.S. at 730 (Stewart, J., concurring). 
be enjoined. ${ }^{352}$ Were it true that, because of superior credibility, all agent disclosures of this sort are as dangerous as private citizen revelations that have actually been shown to threaten "direct, immediate and irreparable" harm, one could readily support the CIA's request. But it simply cannot be that the force of an agent's credibility is so strong that even the most borderline piece of "confidential" information merits injunctive protection. Or, at the very least, it should not be assumed in the absence of a convincing showing by the Agency. Once again, the CIA's restraints sweep further than necessary; they cannot be justified as the least restrictive means of solving this particular problem.

\section{Conclusion}

The restraints imposed by the CIA secrecy-contract regime tread heavily upon first amendment freedom. No countervailing state interest offsets this harm to justify the requirement of prepublication review. Accordingly, secrecy agreement signers should not labor under a perpetual obligation to obtain prior agency approval of their "CIA-related" speech. Snepp $v$. United States, ${ }^{353}$ which held to the contrary, was wrongly decided and should be reconsidered at the first opportunity. The CIA's subordinate demand that its agents refrain from disclosing classified and classifiable information is, however, proper, provided it refers solely to information gained during CIA employment. Mere breach of this duty should not be enjoined, but suits for subsequent sanction are constitutional. Nevertheless, actions for either breach of contract or breach of trust remain improper: The CIA cannot resort to those enforcement weapons that require no showing of scienter.

352 It is hard to see how this imbalance would be redressed in any way either by mandating prepublication review or by allowing the CIA to punish agents who disclose classifiable information without scienter.

353444 U.S. 507 (1980) (per curiam). 
Appendix A

\section{Secrecy Agreement}

1. I, Frank W. Snepp, III, understand that upon entering on duty with the Central Intelligence Agency I am undertaking a position of trust in that Agency of the Government responsible to the President and the National Security Council for intelligence relating to the security of the United States of America. I understand that in the course of my employment $I$ will acquire information about the Agency and its activities and about intelligence acquired or produced by the Agency.

2. I have read and understand the provisions of the Espionage Act, Title 18, USG, secs. 793 and 794, and I am aware that unauthorized disclosure of classified information relating to the national defense may subject me to prosecution for violation of that Act, whether such disclosure be made while I am an employee of the Gentral Intelligence Agency or at any time thereafter.

3. In addition, however, as I am undertaking a position of trust, I have a responsibility to the Central Intelligence Agency not to disclose any classified information relating to the Agency without proper authorization. I undertake, therefore, not to discuss with or disclose to any person not authorized to hear it such information relating to the Central Intelligence Agency, its activities, or to intelligence material under the control of the Agency. I further understand that this undertaking is a condition of my employment with the Central Intelligence Agency, that its violation may subject me to immediate dismissal for cause or other appropriate disciplinary action, and that this undertaking shall be equally binding upon me after my employment with the Agency as during it.

4. I understand that the burden is upon me to ascertain whether or not information is classified and if so, who is authorized to receive it, and, therefore, I will obtain the decision of authorized officials of the Agency on these points prior to disclosing information relating to the Agency, and failure to obtain such a decision will be grounds for my dismissal.

5. I understand that my unauthorized action or utterance in the nature of a publication or which would reasonably be expected to result in publicity on intelligence or intelligence activities would be in violation of Government and Agency regulations and would be grounds for my dismissal. 
6. I understand that for all grievances and complaints there are established procedures within the Agency permitting appeal by any employee of the Agency and to carry any such grievance or complaint outside the Agency will be considered a violation of the undertaking set forth above in paragraph 3. If the appeal procedures are inadequate in any situation, I am aware that the Inspector General is at all times available to any employee with a legitimate criticism, grievance, or complaint.

7. I further understand and agree that my employment by the Central Intelligence Agency is conditioned upon my understanding of and strict compliance with CIA Security Regulations and the appendices thereto.

8. Inasmuch as employment by the Government is a privilege not a right, in consideration of my employment by CIA I undertake not to publish or participate in the publication of any information or material relating to the Agency, its activities or intelligence activities generally, either during or after the term of my employment by the Agency without specific prior approval by the Agency. I understand that it is established Agency policy to refuse approval to publication of or participation in publication of any such information or material.

9. I agree that all information or intelligence acquired by me in connection with my official duties with the Central Intelligence Agency remains the property of the United States of America, and I will surrender, upon demand by an appropriate official of the Agency or upon separation from the Agency, any material relating to such information and intelligence in my possession.

10. I take the obligation set forth freely, without any mental reservations or purpose of evasion. 


\section{APpendix B}

\section{Termination Secrecy Agreement}

1. I, Frank W. Snepp, III, am about to terminate my association with the Central Intelligence Agency. I realize that, by virtue of my duties with that Agency, I have been the recipient of information and intelligence that concern the present and future security of the United States of America.

2. I have read and understand the provisions of the espionage laws (sections 793, 794, and 798 of Title 18, United States Code) and I am aware that unauthorized disclosure of classified information relating to the national defense may subject me to prosecution for violation of those laws. Furthermore, I am aware that the National Security Act of 1947 specifically requires the protection of intelligence sources and methods from unauthorized disclosure.

3. I will never, divulge, publish, or reveal by writing, word, conduct, or otherwise any classified information, or any information concerning intelligence or CIA that has not been made public by CIA, to any unauthorized person including, but not limited to, any future governmental or private employer or official without the express written consent of the Director of Central Intelligence or his representative.

4. I do not now have in my possession, custody, or control, nor am I retaining or taking away from CIA, any classified or unclassified documents or materials that are the property of CIA, or the custodial responsibility of CIA, having come into my possession as a result of my duties with GIA or otherwise.

5. I have been invited to submit in writing any monetary claims that I may have against CIA or the United States Government that may in any way necessitate the disclosure of information described herein. I have been advised that any such claims will receive full legal consideration. In the event, however, that $I$ am not satisfied with the decisions of CIA concerning any present or future claims I may submit, I will not take any action to obtain satisfaction without prior written notice to CIA, and then only in accordance with such security advice as CIA will furnish.

6. During my exit processing and during my period of employment with the Central Intelligence Agency, I have been given an opportunity to report all information about the Agency, its personnel, and its operation that I consider should receive official cognizance. 
Therefore, I am not aware of any information that it is my duty, the national interest or otherwise, to disclose to the Central Intelligence Agency, nor am I aware of any violations or breaches of security that I have not officially reported, except as set forth on attachments to this sheet.

7. I will report without delay to the appropriate CIA officials, or the Federal Bureau of Investigation, any incident wherein an attempt is made by any unauthorized person to solicit classified information from me.

8. I have been advised that in the event I am called upon by the properly constituted authorities to testify or provide information that I am pledged hereby not to disclose, I will notify CIA immediately; I will also advise said authorities of my secrecy commitments to the United States Government, and I will request that my obligation to testify be established before I am required to do so.

9. I have read and understand the contents of this agreement and voluntarily affix my signature hereto with the full knowledge that it was executed for the mutual benefit of myself and the United States Government. I have read section 1001 of Title 18, United States Code and am aware that the making of a false statement herein or otherwise may be punished as a felony. With this understanding, I state that the information I have given is, to the best of my knowledge and belief, correct and complete, and agree that it may be used by the Government in carrying out its duty to protect the security of information that affects the national defense of the United States.

10. I understand that this agreement will be retained in the files of the Central Intelligence Agency for its future use or for reference by me at any time in the future that I may be requested or ordered to testify or disclose any of the matters included within the scope of this agreement. 